\title{
Bankacılık Hizmetlerinde Yapay Zekâ Kullanımı
}

\author{
Use of Artificial Intelligence in Banking Services
}

\author{
Ahmet Illker Akbaba1 ${ }^{1 D}$ \\ Çağla Gündoğdu²(D) \\ ${ }^{1}$ Department of Business, Erzurum Technical University, Erzurum, Turkey \\ ${ }^{2}$ Master of Business, Erzurum Technical University, Erzurum, Turkey
}

\section{Özet}

Sanayileşme sürecinin dördüncü adımı olan endüstri 4.0 ileri teknolojileri içeren bileşenleriyle, bilgisayar programları ve makineleri kullanarak hizmet ve ürün üretiminde insan gücünün minimize edilmesi ve bununla beraber yürütülen süreçlerin minimum maliyet, hı, esneklik ve uyumluluk derecelerinin artırıldığı bir sistem olarak adlandırılabilir. Dördüncü sanayi devrimi birden fazla bileşeni kapsamaktadır. Bu bileşenlerden birisi olan yapay zekâ kavramı ise bilgisayar yazııımlarıyla ses tanıma, akıl yürütebilme, insan düşüncelerini yapay hücrelerle taklit edebilme, duyguları tanımlama, duyguları anlama ve algıya yönelik tepki verme ile hareketi başlatma gibi yeteneklere sahip kodlamalar bütünüdür. Yapay zekâ, kullanıcılar ve firmalar için büyük oranda sunduğu faydalarla bugün silahlı kuvvetler, güvenlik sistemleri, sivil havacılık, pazarlama ve reklamcılık gibi birden fazla alanda tercih edilmektedir. Yapay zekânın en çok kullanıldığı alanlardan birisi de sürekli gelişen ve dinamik bir sektör olan bankacılık alanıdır. Bankacılıkta devam eden e-dijital dönüşüm süreçleri ve dijital bankacılık uygulamalarında sunulan hizmet üretimi sürecinde yapay zekâ tabanlı aplikasyonlar, web siteleri, çevrimiçi uygulamalar, sesli yanıt sistemleri ve sanal asistanlar kullanılmaya başlanmıştır. Bu çalışmada da genel olarak yapay zekâ kavramının tarihsel gelişimi ve kullanım alanlarına değinilerek özelde de yapay zekânın bankacılık sektörü için önemi ile sektördeki kullanım alanları Türkiye Bankalar Birliği'nden alınan veriler ışığında incelenmiştir.

Anahtar kelimeler: Yapay zekâ, bankacılık hizmetleri, endüstri 4.0

\section{Abstract}

Industry 4.0, the fourth step of the industrialization process, can be described as a system in which minimizing the labor force in the production of services and products and increasing the speed, flexibility, and compatibility of the processes carried out at minimum cost by using computer programs and machines with its components containing advanced technologies. The Fourth Industrial Revolution includes more than one component. One of these components, the concept of artificial intelligence, is a set of codings with abilities such as voice recognition with computer software, reasoning, imitating human thoughts with artificial cells, identifying/understanding emotions, reacting to perception, and initiating action. Artificial intelligence is preferred in multiple fields such as armed forces, security systems, civil aviation, marketing, and advertising, due to the benefits it offers to users and companies to a large extent. One of the areas where artificial intelligence is used the most is the banking field, which is a constantly developing and dynamic sector. Artificial intelligence-based applications, websites, online applications, voice response systems, and virtual assistants started to be used in the ongoing e-digital transformation processes in banking and the service production process offered in digital banking applications. In this study, the historical development of the concept of artificial and its usage areas in general, the importance of artificial intelligence for the banking sector, and its usage areas in the sector were examined in the light of the data obtained from The Banks Association of Turkey.

Keywords: Artificial intelligence, banking services, industry 4.0

Akbaba, A. i. ve Gündoğdu, Ç. (2021). Bankacılık Hizmetlerinde Yapay Zekâ Kullanımı. Journal of Academic Value Studies, 7(3), $298-315$. http://dx.doi.org/10.29228/javs.51603

\footnotetext{
*E-mail address: cagla.gundogdu49@erzurum.edu.tr (Corresponding Author)
} 


\section{Giriş}

İçerisinde bulunduğumuz yüzyılın endüstriyel devrimi olan 4. Sanayi devrimi ya da diğer bir adıyla Endüstri 4.0, ürün ve hizmet üretiminde modern ve verimli gelişmeleri beraberinde getirmiştir. Ürün üretimlerinde olduğu kadar hizmet üretimlerinde de Endüstri 4.0 bileşenlerinin kullanılmasıyla verilerin toplanması, işlenmesi ve sınıflandırılması; doğru hizmet kalitesini sunabilmesi ya da maliyetlerin iyileştirilmesiyle beraber sürekli gelişim ve dijital dönüşümler için büyük bir etken olmuştur.

Endüstri 4.0 kavramıyla beraber hizmet sektöründe atılan adımlardan birisi de müşterilere ulaşılan kanalların yapay zekâ teknolojisine entegre edilmesidir. Yapay zekâ kullanımıyla beraber hizmet üreticilerinin müşterilere kolay ulaşımı, farklı cihazlar üzerinden iletişim kurabilmeleri, kullanıcıları kategorize edebilmeleri, aynı anda birden fazla müşteri talebini karşılama, dünyanın her yerinde ürünlerinin her saat aralığında kullanılmasına olanak sağlayan sistemlerin işletilebilmesi ve işlemlerin gerçekleştiği zaman diliminde doğru güvenlik aksiyonlarının alınabilmesi sayesinde hem hizmet kalitesinin artması hem de tüm bu süreçlerin yine yazılımlarla diğer uygulamalara nispeten daha rahat denetlenebilmesi firmaları yapay zekâ kullanımına yöneltmiştir.

Hizmet üretimleri içerisinde dinamik ve sürekli gelişim halinde olan bankacılık sektörü ise bu süreçte hem çağın gerekliliğini yakalayabilmek hem de müşteri deneyim ofisleriyle iş birliği yaparak müşteri taleplerini doğru karşılayabilmek adına büyük oranda dijital dönüşümler geçirmiş; ürün ve hizmetlerini Sesli Yanıt Sistemleri (IVR-IVN), internet bankacılığı, mobil bankacılık, QR kod sistemleri ve Chat Botlar aracılığı ile sunmaya başlamıştır.

Bankacılıkta yaşanan bu dijital dönüşüm süreci kapsamında bankalar, müşterilerine ulaştığı uygulamaları yine dördüncü sanayi devriminin bileşenlerinden biri olan yapay zekâ ile destekleyerek doğru ürün ve/veya hizmeti ilgili müşteriye sunabilme, iş süreçlerini optimal yönetebilme, müşteri taleplerini tahmin edebilme, finansal danışmanlık, güvenilirlik ve güvenlik kapsamında kendilerini geliştirme ve yeni nesil bankacılık çözümlerine yönelme imkânı bulmuştur.

\section{Yapay Zekâ}

Teknolojik gelişmelerle beraber insanların günlük yaşamlarında kullandıkları nesnelerle olan bağı da artmıştır, günlük yaşamımızın bir parçası haline gelen teknolojik ürünler genel olarak bilgisayar programları ile bağdaştırılmış ve bunun sonucunda da insan düşünceleri ile nesneler arasında bir bağ oluşması ihtiyacı gözlemlenmiştir, tüm bu faktörleri göz önüne aldığımızda yapay zekâ kavramına olan ilgi artmış ve günümüzde özellikle yapay sinir ağları, doğal dil işlemeye yönelik programlar geliştirilmeye yoğunlaşılmıştır (Öztürk ve Şahin, 2018: 25).

Yapay zekâ kavramı önceki yıllarda daha çok mühendislik alanıyla ilişkilendirilirken; dijital dönüşümler ve teknolojik gelişmelerle berber tüm alanlarda olduğu gibi artık sosyal bilimler alanında da ilgiyle çalışılan bir konu haline gelmiştir.

Yapay zekâ kavramı günümüzde daha çok robotların insan formuna benzemesiyle ilişkilendirilse de aslında birden fazla disipline entegre edilmiştir. Mühendislik, haberleşme, elektronik, mekanik, felsefe gibi birden fazla alanda çalısıılmaktadır. Yaşanan teknolojik gelişmelerle beraber insanların yapay zekâ beklentilerini de artırmıştır bu beklentilerle beraber çalışmalar da büyük bir ivme kazanarak günlük hayatın her alanına yapay zekâ uyum sağlamaya başlamıştır (Öztürk Ve Şahin, 2018: 23).

1960'lı yıllar itibariyle hayatımızda yer alan ve uygulamaları yazılımlar aracılı̆̆ıla yapabilen basit bilgisayarların ortaya çıkmasıyla yapay zekâ kavramı da tartışılmış ve günümüzde endüstri 4.0 bileşenlerinden birisi olarak yer almıştır (Scrop, 2018: 2'den aktaran Gacar, 2019: 390).

\subsection{Tanımı}

Yapay zekâya dair literatürde birçok tanım yapılmış olup bu tanımlardan bazıları aşağıda verilmiştir:

Birden fazla işlem için; algılama, öğrenme, muhakeme ve harekete geçebilme kabiliyeti olan bununla beraber yöneten, güvenilebilir ve açıklanabilir, programlama ile yönetilen sistemler bütünüdür (Gunning 2017: 2).

Yapay zekâ kavramı aslında düşünsel olarak insani becerileri taklit edebilme, iletişim kurabilme, öğrenme, gelişme ve uyum sağlama kabiliyeti olan yazılımsal teknolojiler olarak adlandırılabilir (Wirtz vd., 2018: 3-4'ten aktaran Tamer ve Övgün, 2020: 782). 
Mevcut problemin bilinmesine rağmen çözüm algoritmasının oluşturulamadığı durumlarda çözümlenemeyen sorun için çıkarımlar yapabilen, insan eliyle üretilmiş algoritma üretebilen bilgisayar modellemesidir. Bununla beraber gelişen, öğrenen ya da keşfedebilen bir sistemdir (Köroğlu, 2017).

Yapay zekâ; insan zekâsının ileri düzeyli sistemlerle beraber mantık ve matematiksel olgular çerçevesinde üretilmiş kalıcı olan, kopyalanabilen, en küçük detayların dahi muhafaza edilebildiği sistemler bütünüdür (Topakkaya ve Eyibaş, 2019: 85).

\subsection{Tarihçesi}

Yapay zekâ tarih öncesi çağlardan günümüze kadar incelenmiştir. Illk olarak 1965-1970 yılları arasında gelişim süreci yavaş ilerlemiştir, 1970-1975 yılları arasında gelişmelere yönelik bazı adımlar atılmıştır. 1975-1980 yıllarında yükselişe geçerek birçok programlamanın temeli oluşmuştur, 1980 sonrası ise robotlar artmış ve programlamada gelişmeler yaşanmıştır. Günümüzde inovatif olarak adlandırılan bu dönem gelişen teknolojinin doğurduğu ihtiyaçlara yönelik şekillenmekte ve halen devam eden kompleks uygulamaların gelişimiyle sürdürülen bir dönemdir (Pirim, 2006: 83).

Leonardo Da Vinci 15. Yy'da yapay zekâya yönelik çalışmalar yapmış bununla beraber, Jacques de Vaucanson 1700 'lü yıllarda flüt çalabilen bir otomat yapmıştır. 1940'lı yıllarda Shannon'un labirent çözümleyebilen bir fare tasarlaması bir örnektir (Barutçuoğlu 2001: 2 ve 2001: 4'ten aktaran Kuşçu, 2015: 30).

1956 yılında MC Charthy'in Amerika Birleşik Devletleri'nde yer alan Dartmounth'da düzenlenen bir konferansta yapay zekâ kavramı ilk kez yer aldı (Akın 1997'den aktaran Kuşçu, 2015: 31).

\section{Tablo 1. Yapay Zekânın Kronolojik Özeti}

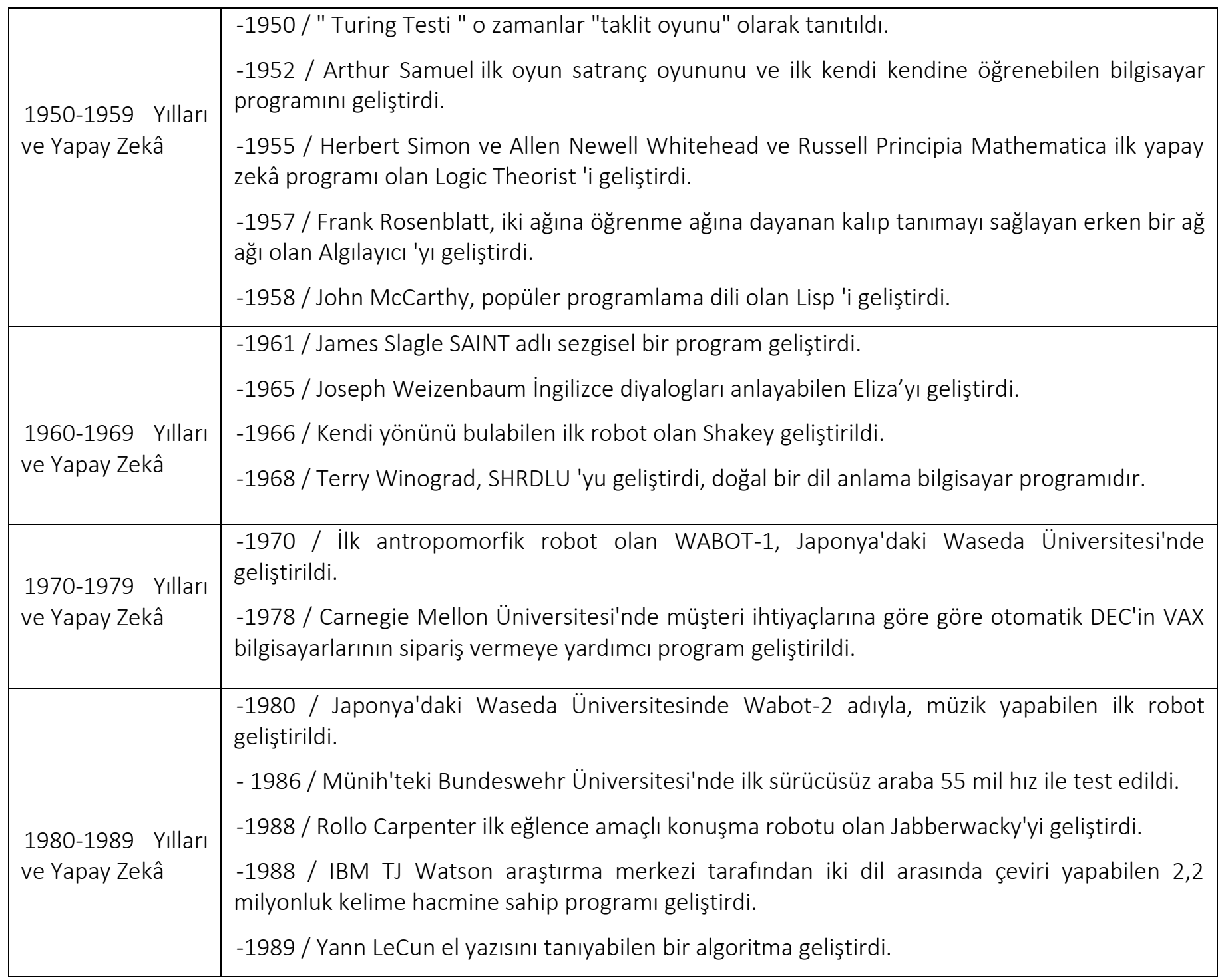




\begin{tabular}{|c|c|}
\hline $\begin{array}{l}\text { 1990-1999 Yılları } \\
\text { ve Yapay Zekâ }\end{array}$ & $\begin{array}{l}\text {-1995 / Richard Wallace, verileri toplayabilen chatbot ALIC'yi geliştirdi. } \\
\text {-1997 / Illk kez bir yapay zekâ (Deep Blue) satranç turnuvasında dünya şampiyonunu yendi. } \\
\text {-1998 / Hampton ve Furbby, ilk ev robotunu geliştirdi. }\end{array}$ \\
\hline $\begin{array}{l}\text { 2000-2018 Yılları } \\
\text { ve Yapay Zekâ }\end{array}$ & $\begin{array}{l}\text { - MIT çalışanı Cynthia Breazeal, duyguları tanıyan ve simüle edebilen bir robot geliştirdi } \\
\text {-2000 / İnsan hızında yürüyebilen ilk robot olan Honda'nın ASıMO robotu tanıtıldı. } \\
\text {-2006 / Etzioni, Banko ve Cafarella okuyabilen robotu geliştirdi. } \\
\text {-2009 / spor haberleri yazan Stats Monkey programı, Northwestern ÜniversitesiA tarafından } \\
\text { geliştirildi. } \\
\text {-2012 / Dean ve Rastgele } 10 \text { milyon üzerinde Youtube videosuna tepki verebilen bir program } \\
\text { geliştirdi. } \\
\text {-2012 / Siri'yi Apple tarafından tanıtıldı ve cihazlara entegre edildi. } \\
\text {-2013 / Facebook yedi yüz milyon kullanıcıyı sınıflayabilen Deplearn uygulamasını geliştirdi. } \\
\text {-2014 / Vicarious ve ekibi CAPTCHA'yı çözebilen bir program geliştirdi. } \\
\text {-2014 / Innsan düşüncelerini anlayabilmeye programlı olan bununla beraber insanların sorularını } \\
\text { ve duygularını tanımlayabilen sanal asistan Amelia geliştirildi. } \\
\text {-2015 / Maryland üniversitesi YouTube'dan videoyu izleyerek yemek pişirmeyi öğrenen robotlar } \\
\text { geliştirdiler } \\
\text {-2015 / Google, kendi kendine video oyunu öğrenip usta olan yapay zekâ geliştirdi. } \\
\text {-2015 / Google, drone'lar için yapay zekâ geliştirdiğini açıkladı. } \\
\text {-2016 /Ars Technica tamen yapay zekâ tarafından yazılan ilk kısa filmi yayınladılar. } \\
\text {-2017 / NVıDı otomobili kullanabilen PilotNet'i geliştirdi. } \\
\text {-2017 / Google, video içeriğini analiz edip arama sonuçlarına ekleyebileceği bir aplikasyon olan } \\
\text { "Makine Öğrenme” uygulamasını sunmaya başladı. } \\
\text {-2018 / Blockchain tabanlı bir yapay zekâ sistemi olan SingulartyNet geliştirildi. }\end{array}$ \\
\hline
\end{tabular}

Kaynak: Cebero, 2018

\subsection{Fonksiyonları}

Yapay zekâ bazı kavramlarla ilişkilendirilmektedir. Yapay zekâ kavramının yeteneklerini oluşturan görüntü, ses, frekans ve taklit yeteneği bazı fonksiyonlara ve bu fonksiyonların özelliklerine aşağıda değinilmiştir.

\subsubsection{Görüntü Işleme}

Görüntü işleme teknolojisi, dijital bir görüntünün elde edildikten sonra sayısal bir dille bölümlendirilmesi ve analizinin yapılması aşamalarıyla elde edilen görüntü verisinin bazı algoritmalar uygulanarak çıktıların elde edildiği bir süreçtir (Soyhan vd., 2021: 470).

Bilgisayar teknolojilerinin gelişmesiyle görüntü işlemeye olan ilgi de artmıştır. Daha iyi bir görüntü işleme süreci için yapay zekâ faktörüne yönelmek daha doğru olacaktır. Ilgili algoritmalarla yapay zekânın optimizasyon problemlerine uygulanması mümkündür (Zan ve Daha, 2019: 42).

Yapay zekâ görüntü işleme teknolojisi için sürücüsüz araçlar örnek verilebilir.

\subsubsection{Ses Tanıma}

Bilgisayarlar üzerinde işlenmesi istenilen ses verisi uygun cihazlar aracılığıyla alınır, dijital olarak dönüştürülür ve frekanslar oluşturulur. Kullanılan cihazlar ses içerisindeki kirlilik ve kayıpları en düşük seviyeye getirir, frekanslardan oluşan harf ya da kelimeler rakamlara dönüştürülür. Ses verileri dönüşümü sonrasında kelimelerin tahmin edilmesi adımına geçilir. Cümle yapısını oluşturan bütünler sisteme tanıtılır, doğru sınıflandırma kriterleri oluşturulur ve test edilerek sistemlere entegre edilir (Ateş, 2019: 7). 
Yapay zekâ ses tanıma özelliğine Now, Echo, Cortana örnek olarak gösterilebilir.

\subsubsection{Muhakeme}

Yapay sinir ağları aracılığıyla insanların düşünme becerisini taklit ederek öğrenme, anımasayabilme ve genele uyarlayabilme yöntemiyle yeni verilerin oluşturulması ve bu verilerin kodlanması ile analiz edilebilmesine dayanan bir fonksiyondur (Öztürk ve Şahin, 2018: 27).

Yapay zekâ ve muhakeme özelliği için tarayıcı aramalarının özelleştirilmesi ya da alışveriş sitelerinin ürünleri alıcıların arama verilerine göre sınıflandırabilme yetisi örnek verilebilir.

\subsubsection{Doğal Dil İşleme}

Yapay sinir ağları ve denin öğrenme teknolojisi ile metinlerin tasnif edilmesi, bölümlendirilmesi, duygularla ilişkilendirilmesi adımlarının dijitale dönüştürülerek sayısal olarak ifade edilmesi, elde edilen verilerle yeni bilgilerin çıkarılması, yeni sözcük ekleme ya da çeviri yapabilme gibi aşamaları içeren bir fonksiyondur (Küçük ve Arıcı, 2018: 80).

Doğal dil işleme teknikleri genelde veri tabanları üzerinden elde edilen verilerin öncelikle ayıklanması ve sonrasında metinleri oluşturan kelimelerin sayısal kodlarla ifade edilmesi temeline dayanır. Sisteme girişleri yapılan veriler ilk etapta analiz edilir ve mantıksal bir örüntü işlenir. Sonraki adımda ise elde edilen çıktılar bir veritabanına aktarıır. Bu veri tabanında; elde edilen kelimeler, kelime hacmi, kelimelerin kök ve eklerinin ayrımı, kelimelerin hangi düzenle birleştiği ve bu dizinde yer alan kısıtları içeren bir algoritma bulundurur (Aggarwa, 2011: 43).

Doğal dil işleme ve yapay zekâ için tarayıcılarda kullanılan arama cümlelerinin düzeltilmesi, çevrimiçi çeviri uygulamaları, navigasyonlar ve bununla beraber sanal asistanlar ile yazılı iletişim kurabilme yetilerinin kullanıldığı uygulamalar örnek verilebilir.

\subsubsection{Yapay Sinir Ağları}

Yapay sinir ağları, insan beyninin taklit edilmesine dayanır. Bu ağlar yapay sinir hücrelerinin birleşiminden oluşur ve öğrenebilme yetisini işlenen örneklemler üzerinden edinir. Uyum gösterebilme, karar alma, tolerans tanıyabilme ve hataları hesaplayabilme gücüne sahip olması bu ağlara ayırt edebilme yeteneğini de kazandırır (Öztemel, 2003: 15).

\subsection{Kullanım Alanları}

Sürekli gelişen teknoloji ve dijital dönüşümlerle beraber yapay zekâ kavramı da yaşamımızın her alanında yer edinmeye başlamıştır. Yapay zekâ, verilerin daha hızlı elde edilebilmesi, işlenmesi, sınıflandırılabilmesi ve yapay zekâ fonksiyonlarının birleşmesi sonucunda eğitim, sağlık, eğlence gibi hayatımızın bir parçası haline gelen birden çok sektörde kullanılmaya başlanmıştır. Aşağıda yapay zekânın kullanıldığı bazı sektörlere değinilmiştir.

\subsubsection{Sağlık}

Sağlık sektöründeki yapay zekâ kullanımı öncelikle tedavi, doğru teşhis ve hasta verilerinin doğru işlenmesi akışlarında en uygun uygulamaların kullanılması için bir gelişme olmuştur sonrasında ise yapay zekânın kapsadığı derin öğrenme, makine öğrenmesi gibi alt dallarıyla hem maliyetlerin azalması hem personelin yeterliliğinin ölçülmesi hem de bir veri tabanı oluşturulması için önemli bir etkendir (Akalın ve Veranyurt, 2020: 132).

Sağlık açısından hastalıkların teşhisinde kan basıncı, nabız ya da kalp ritmi gibi vücut tarafından verilen tepkiler oldukça önemlidir. Yapay zekâ kavramının cihazlara entegre edilmesiyle beraber bu ölçümlerde daha hassas davranan cihazlar üretilmeye başlanmıştır. Bununla beraber insanlara ait deri dokusunu taklit edebilen, dokunma işlevi olan sensör tabanlarıyla e-cilt uygulamaları da geliştirilmiştir. Yine son dönemlerde yapay zekâ tabanlı ve bir ana bilgisayar aracıllğıyla kontrol edilebilen ve hasta bilgilerini işleyerek daha fonksiyonel hale gelen robotik sistemler yaşlıların veya kendi bakımını yerine getiremeyen hastaların tedavisinde kullanılmaya başlandı (Zang vd., 2015).

Yapay zekâ kavramının akıllı telefonlarla ilişkilendirilmesiyle beraber cihaz üreticileri de günlük hayatımızda bize yardımcı olacak özellikleri içerisinde barındıran uygulamalarla bu telefonları tanıtmaya başladı. Örneğin Samsung, S3 serisi itibariyle telefonlarında "Healt" uygulamasına yer verdi. Bu uygulama sayesinde kalp atışınızı ölçebilir, kilo ve boy oranınızı sisteme yazdıktan sonra kitle indeksinizi hesaplayabilir aynı zamanda basit egzersiz, günlük su tüketimi ve alınan kafein miktarı verilerini sisteme ekleyerek rutin telefon kullanımlarında sağlık verilerini kontrol etme imkânına sahip olursunuz (https://www.samsung.com/tr/apps/samsung-health/).

\subsubsection{Eğitim}

Eğitimde yapay zekâ kullanımlarında bilgiye hızlı ve kolay ulaşım, esnek öğrenme saatleri, tüm öğrenciler kapsadığı için daha ulaşılabilir, verimli, eşit ve sürekli öğrenme fırsatı sunabilir. Eğitimde yönetim kısmı içinse maliyetlerin 
düşürülmesi, uygun bütçeleme, denetleme, başvuru ve kayıt süreçlerinin yönetilmesi için optimalliği büyük oranda artırabilecek yöntemler uygulanabilir (İşler ve Kılıç, 2021: 4).

Bireysel öğrenme değişkeninde öğrencilerin hangi yöntemle daha sağlıklı bir öğrenme süreci geçirdiklerini yapay zekâ kavramıyla beraber birden fazla sınıflandırma sayesinde tespit edilebilir, bulanık mantık algoritması kullanılarak öğrencilerin öğrenme tekniklerinin sınıflandırıldığı yine yapay zekâ tabanlı bir web sitesi ya da çevrim içi uygulamalarla öğretilmek istenen bir bilgi ya da materyalin görsel, işitsel ya da dokunsal formları öğrencilere sunularak eğitimde verimlilik artışı hedeflenebilir (Kazu ve Özdemir, 2019: 464).

Makine öğrenme ya da yapay sinir ağları yeteneğiyle yapay zekâ kavramı eğitimde birden fazla alanda kullanım imkânı sağlayabilir. Örneğin LLC şirketi tarafından sunulan Turnitin ve plagiarism.org programları sayesinde benzerlik oranları tespit edilerek olası kopyalama faaliyetlerinin önüne geçilirken özgün içeriklerin ortaya konmasına da katkı sağlanmıştır (https://www.turnitin.com/tr).

\subsubsection{Turizm}

Gelişen teknoloji kavramıyla beraber seyahat kavramı da gelenekselden daha farklı bir hale gelmiştir, çevrimiçi uygulamalar, firmaların kullandığı aplikasyonlar ve akıllı telefonlarla birlikte turizm faaliyetlerinde de yeni nesil teknolojiler önemli önemli bir rol oynamaktadır (Hunga ve diğerleri, 2017'den aktaran Bahar ve Yüzbaşıŏlu 2019: 74).

Yapay zekâ uygulamalarıyla çeviri uygulamaları, kişiselleştirilmiş hizmet, çevrimiçi destek uygulamaları, aplikasyonlar üzerinden ulaşılabilirlik, akıllı şehirler, yapay zekâ tabanlı ulaşım ve sağlık uygulamaları ile online chek-in gibi sistemlerle turizm sektöründe bir de konaklama yerlerinde sunulan yapay zekâ temelli robotlarla personelin yaptığı işlemler daha profesyonel bir yolla sunulabilir (Topsakal, 2018).

Turizm uygulamalarında son dönemlerde birden fazla yapay zekâ tabanlı aplikasyonlar geliştirilmiştir Expedia, Hipmunk ya da Booking.com gibi uygulamalarla sanal asistanlar sayesinde rezervasyon yapabilir ya da var olan rezervasyonlarında değişiklik ya da iptal işlemini yapabilirler bununla beraber Skyscanner uygulamasıyla beraber yolcular yine havaalanlarında bagaj ya da uçuş süreçleri gibi rutin sorular Chat botlar aracılığıyla yanıtlanmaktadır (https://www.new.com.tr/blog/akilli-turizm-otelcilik-ve-yapay-zekâ-uygulam ).

\subsubsection{Siber Güvenlik ve Savuma Sanayi}

Değişen teknolojik gelişmelerle beraber güvenlik ve ulusal güvenlik kavramları da gelenekselden farklı bir hale dönüşmüştür. Yapay zekâ kavramı ile yüz tanıma, otonom araçlar, dijital ayak izlerinin takibi, konum takip sistemleri ülkelerin savunma sistemleri içerisinde yer almaya başlamıştır. Bu gelişimlerle beraber akıllı savaş kavramı ortaya atılmış ve ülkeler yurt içinde ve uluslararası düzeyde savunma sanayii ve siber güvenlik için yapay zekâ yatırımlarına gün geçtikçe daha fazla önem vermeye başlamıştır. Suç tespitine yönelik geliştirilmeye çalışılan aplikasyonlarla beraber otonom deniz robotları ve dronlara olan ilgi artmıştır (Demirkol, 2020: 421).

Siber savunma sistemleri bir web sitesi, kamu kurumlarına ait dijital veriler ya da ülke güvenliğine dair tüm yabancı ağların siber saldııılarına karşı geliştirilen ağ savunma algoritmalarıdır, yapay zekâ ile yapılan saldırılara karşıı verme, alınan hasarı en aza indirgeme bununla beraber gelebilecek saldırıları önlem makine öğrenimi ile yapılan saldırıların modellenmesi, düzenli olarak denetleme süreci ve gelişecek saldırılara yönelik araştırma ile siber saldırılarda erken uyarı ve önleme adımları kullanılarak güvenlik düzeyi artırılabilir (Şeker, 2020).

Havelsan, Türk Savunma Sanayii sistemlerinin teknolojiye uyumlanması sürecinde; FIVE-ML Ar-Ge projesi kapsamında simülatörler aracılığıyla muharebe esnasında yapılabilecek taktik, olası senaryoların planlanması, eğitim sonrası elde edilen verilerin değerlendirilmesi gibi öğrenebilen yapay zekâ tabanlı ATAKSiM, ANKA, UMTAS, MTÇS yazılımlarına makine öğrenme kabiliyeti olan yapay zekâ tabanlı bir kodlama algoritması oluşturacak bir simülasyon projesinin 2021 yılı sonunda tamamlanacağını belirtmiştir (https://www.havelsan.com.tr/haberler/guncel/havelsanyapay-zekali-simulator-gelistirecek).

\subsubsection{Elektronik Ticaret (E-Ticaret)}

Yapay zekâ kullanımı; internet sitelerinin yararlandığı, kullanıııların ilgi alanlarına göre sınıflandırma, sisteme kaydedilen verilerin kullanıcılar özelinde kaydedilmesi, yapay sinir ağları kullanılarak kişiselleştirilmiş mağaza seçenekleri, problemi tanımlayıp doğru çözüm sürecini uygulayabilme, sanal asistanlarla hızlı cevap verebilme, yönlendirebilme, uygun olmayan kısımların ayrıştırıması ve buna benzer kullanıcılara özgü bir hizmet sunabildiği için e-ticaret siteleri çoğunlukla yapay zekâ tabanlı yazııımlara yönelmektedir (Uğur ve Kınacı, 2006: 348). 
Elektronik ticaret enstrümanlarından olan ve mali denetimi yakından ilgilendiren elektronik faturaların yapay zeka koordinesinde kullanımı, kullanıcıların hile ve usulsüzlüklerini kaynakta engelleme açısından önem arz edecektir (Yanık ve Karadaş; 2013: 140)

Şirketlerin karlıı̆ını artırabilmeleri adına yöneldikleri e-ticaret sistemleri yapay zeka teknolojisi ile desteklendiğinde kurum içerisinde hızlı ve doğru haberleşme, doğru işbirlikleri kurum içerisinde çalışanların memnuniyetinde olumlu bir etki oluştururken bununla beraber müşteriyi tanıyan sistemler aracılığıyla elde edilen bilginin doğru kullanılmasıyla doğru ürünlerin tavsiye sistemlerince aktarımı rakiplere karşı üstünlük olarak geri dönecektir ve yine inovasyon süreçlerine de pozitif bir kazanım oluşturacaktır (Yıldırım ve Özdemirci, 2019: 40).

E-ticaret sistemlerinde müşteriler için hızlıca ve konuşma yeteneğiyle işlem yapan yapay zekâ tabanlı chatbot uygulamaları son dönemlerde sıkça kullanılmaktadır, örneğin Microsoft Luis ile işletmeler kodlama yapmadan kullanıcılarına chatbot desteği sunabilir, Türkiye ( mesela MindBehind gibi) ve dünya üzerinde bir çok e-ticaret sitesi Luis desteğiyle kendi chat botlarını müşterilerine sunmaktadır (https://docs.microsoft.com/tr-tr/azure/cognitiveservices/luis/what-is-luis ).

\subsubsection{Otomotiv}

Endüstri 4.0 süreciyle beraber otomotiv sektöründe de dönüşümler devam etmiştir. Yazılımsal altyapının gün geçtikçe gelişmesiyle beraber yapay zekâ kapsamında üretilen araçlar da değişmiştir. Tüketici taleplerinin tahmini, kurum içinde kullanılan teknolojik yöntem ve hizmet süreçlerinde dijitalleşme devam etmektedir. Sürücüsüz araçlar ve bunların mobil aplikasyonlarla entegresi yine bu sektörde yapay zekâ kullanımına bir örnektir (Sürmen, 2019: 109).

Otomotiv sektörü birden fazla bileşeni ve diğer sektörlere yakınlığıyla ön plana çıkan bir alandır. Otomotivde yapay zekâ kavramı ile birden fazla işlevsel uygulama sunulabilir örneğin yapay sinir ağları ve makine öğrenme kavramıyla berber otomotiv sektöründe talep tahmin uygulamaları yapılarak yıllar ve dönemsel bazlı uygulamalar tespit edilerek uygun hizmet ve kampanya sunma faaliyetlerini işletmeler daha sağlıklı yönetebilir (Karatlı vd., 2012: 98).

Otomotiv sektöründe yapay zekâ ile birleştirilen araçlarla birlikte şirketler de dijitalleşmeye yönelmiştir, örneğin Bedford, Massachusetts merkezli DataRPM şirketi makine öğrenme yöntemini kullanarak otomobil parçalarında önceden oluşabilecek arızaları tespit etmeye yönelik çalışmalar yapmaktadır bununla berber MIT'nin bir projesi olan Optimus Ride projesi ise kısıtlı alanlarda ya da küçük şehirlerde kullanılmak üzere akılı park sistemi olan elektrikli araçlar üretmiştir (https://listelist.com/otomotiv-endustrisi-yapay-zeka/ ).

\subsubsection{Havacilık}

Havacılık sektöründe dijitalleşme süreciyle beraber yapay zekâ kullanımı da artmıştır özellikle havaalanlarında tercih edilen; akıllı̈ ödeme, parmak izi ve yüz tanıma teknolojisi, sanal kule ve asistanlar, yapay zekâ ile güvenlik analizleri, akılı aydınlatma, sağlık hizmetleri ve insansız operasyon süreçleri ile hizmet kalitesinin gün geçtikçe artmasıyla beraber aynı zaman da niye zaman ve maliyet açısından tasarruf sunmaktadır (Türkay ve Artar, 2021: 92).

Askeri havacılıkta ise yapay zekâ kullanımı büyük bir açı̆̆ı kapatmıştır. Kesintisiz uçuşlar, anlık görüntü iletme, hemen müdehale edebilme olanağı sunmaktadır. Yapay zekâ tabanlı IHA'larla beraber orduların silah- mühimmat envanterleri değişmiş, askeri personelin güvenliğini sağlamada ilerleme kat edilmiş ve iHA'larla beraber ulusal güvenliğe tehdit oluşturan faaliyetlerde uygulanan bazı saldırı yöntemleri önemini yitirmiştir (Karakuş ve Katman, 2019: 894).

Türk Silahlı Kuvvetleri envanterinde yer alan yeni nesil taktik, silahlı taktik ve mini IHA'lar Türk Hava- Harp Sanayii için önemli bir adım olmuştur, bunula beraber yeni nesil SiHA'lar da aktif görev yapmaktadır (https://www.ssb.gov.tr/urunkatalog/tr/154/).

\subsubsection{Reklamcilik ve Pazarlama}

Reklamcılık ve pazarlama alanında yapay zekâ uygulamalarıyla müşteri deneyimi kısmında çevrimiçi hizmetler, kişiselleştirilmiş arama bölümleri, fiyat sıralamaları, özlük bilgileri ve geçmiş satın alma verileri analiz edilebilir bu analizler sayesinde firmalar bu verileri kullanarak doğru ürün ve müşteri eşleştirmesiyle beraber zaman ve maliyetlerden tasarruf edebilir, satın alma kararını yöneterek aynı zamanda kâr marjını artırabilirler (Keleş vd., 2017: 112).

Reklamcılık hizmetlerinde kullanılan programlamalarla reklam veren şirketler tüketicilere yönelik daha şeffaf ve mikro bilgiler edinebilir, satın alma davranışlarının takip edilmesi, denetim sürecinin doğru ilerletilebilmesi ve bununla berber bütçeleme faaliyetlerini yönetebilmeleri işletmelerin kaynaklarını etkin ve verimli kullanmada yarar sağlayacaktır (Zeren ve Keşlikli, 2019: 319-320). 
Bir spor firması olan Under Amour, kullanıcılarına yönelik reklam tanıtımlarında ürünler için bir sporcuya ait rutin verilerinin toplanıldığı ve kullanıııya yönelik tavsiyeler iletilen bir yapay zekâ tabanlı chatbot uygulamasını IBM Vatson ile iş birliği yaparak sunması bu sektör için bir örnek olarak gösterilebilir (https://www.endustri40.com/pazarlamadakullanilan-yapay-zeka-araclari/) ).

\section{Bankacılık Hizmetlerinde Yapay Zekâ Tabanlı Uygulamalar}

Geçmiş yüzyılda teknolojinin büyük bir ivme kazanarak gelişmesi içerisinde bulunduğumuz yirmi birinci yüzyılda da yine büyük bir hızla devam etmektedir. Gelişen teknolojiyle birlikte; yeniden şekillenen pazar kavramı, ürün/hizmet üreticilerinin tüm kalemleriyle dijitalleşmeye adım atması ve yerel pazar kavramının giderek öneminin değişmesiyle beraber küreselleşmenin başlaması işletmelerin de üretim faktörlerine bilgi ve teknolojiyi eklemesine zemin oluşturmuş̧tur. İşletmeler değişen bu şartlara uyum sağlamak ve rekabeti sürdürebilmek adına sürdürecekleri dijital dönüşümler yine işletmeler için özellikle pazarlama, maliyet ve verimlilik kavramlarında önemli avantajlar sağlayacaktır (Akbaba ve Özdemir, 2013).

Günümüzde ekonomik faaliyetlerin sürdürülebilmesi risk faktörünün en aza indirgendiği para akışına bağlıdır, bu güvenin sağlanabilmesi adına belirlenen yasal çerçevede hem fon toplayan hem de bu fonları dağıtarak finans piyasasında denge oluşturabilecek finansal kuruluşlara intiyaç doğmuştur, bankalar bu sektörde belirtilen faaliyetleri yerine getiren kurumlar olmuşlardır. Temel işlev olarak kaybolma ve çalınma riskine karşın varlıkların korunduğu ve belirli bir vade farkı ile borçlanma faaliyetlerinin sürdürüldüğü bu işletmeler risklerin ortadan kaldırılmasında önemli bir faktör olduğu için özellikle para akışında ticari faaliyetler için kaçınılmaz bir aracılık biçimi olmuştur (Güçlüay, 2001: 298). Katılım bankaları da alternatif finansman hizmetleri sunan, finansal sektörde faaliyette bulunan, reel ekonomiyi finanse eden ve bankacııık hizmetleri sunan kuruluşlardır (Yanık ve Sümer, 2019).

Finansal işletmeler içerisinde yer alan bankacılık, M.Ö önce 3500 yıllarından günümüze dek devamlılığını sürdüren, kelime kökeni olarak banko kavramından türetilmiş, İtalyancadır bir sözcüktür. Para ve türevi ödeme araçlarının henüz kullanılmadığı takas usulü sistemlerin kullanıldığı dönemlerde dahi bankacılığa yakın izlere rastlanılmaktadır (Çivi, 1985: 19'dan aktaran Sümer, 2019: 487).

Ülkemizdeki finansal yapının en önemli faktörlerinden birisi de para akışının büyük bir bölümünü içerisinde bulunduran bankacılık sektörüdür. Yeni nesil bankacılık faaliyetlerine uyumlu, sermayesinin güçlü olduğu ve bağımsız denetleme kuruluşlarınca ilerlemesine devam eden Türk Bankacılık Sektörü, çağdaş hizmet kalitesi ve işlem hacimleriyle bireysel ve kurumsal kişilere hizmet sunmakta ve gelişimine devam etmektedir (Sümer, 2016: 492).

Bankacılık sektörü içinde bulunduğumuz zaman diliminde çok hızlı gelişmektedir, teknolojinin bu gelişimde etkisi ise artarak devam ediyor. Geleneksel bankacılık sistemlerinde olduğu gibi bankalar artık şubeler ve ATM'lerden ibaret görülmüyor dolayısıyla modern bankacılık sistemlerinde güncel teknolojik uygulamalar artık daha fazla önem arz ediyor. Güncel teknoloji kavramlarından birisi olan yapay zekâ ise; temel bankacılık sistemleri, operasyonel risk birimleri, müşteri deneyim ofisleri ya da teknik ekipler gibi bankaların çeşitli birimlerinde kullanılıyor. Yapay zekâ kullanımıyla; müşteri deneyimleri iyileştiriliyor, maliyet etkinliği artıyor, yeni bankacılık ürünleri tanıtılabiliyor, potansiyel müşteri kitlesine hitap edebilme ve tutundurma faaliyetleri koordineli yürütülebiliyor tüm bunlarla beraber bankaların büyüme süreçlerinde yine bir çarpan olarak teknoloji faktörü yer edinebiliyor. Yapay zekâ kavramı sadece bireysel bankacılıkta kullanılan bir teknoloji olmadığı gibi kurumsal bankacılıkla beraber, yatırım, katılım ve kalkındırma bankacılığında da kullanılmaktadır (Kaur vd., 2020: 583-584).

Bankaların veri havuzlarının hacmi tahmin edilebileceği gibi çok geniştir, bu verilerin işlenmesi, sınıflandıııması, anlamlı sonuçların elde edilmesi, sonuçların analiz edilmesi gibi adımlar yapay sinir ağları ile sağlanmaktadır (Payne ve Dharwadkar, 2017: 876).

\subsection{Literatür Taraması}

Ortiz ve diğerleri (2016). Çalışmalarında güvenlik ve yapay zekâ kavramını ele almış, bankacılık sektöründe yapay zekâ tabanlı uygulamalar geliştirilirken yazılımlarda Python programlamanın veri güvenliğine etkisi üzerinde durulmuş ve bazı programlamaların yapay zekâ güvenliğini nasıl etkilediğine değinmiştir.

Altınırmak ve Karamaşa (2016). Çalışmalarında bankaların finansal risklerini önceden tahmin edebilecek iki farklı yöntemle erken uyarı sistemine yönelik inceleme yapmışlardır. Incelemede Vektör Analiz Sistemi'nin Yapay Sinir Ağları'na göre daha uygulanabilir olduğu gözlemlenmiştir. 
Zorić (2016). Çalışmasında yapay sinir ağlarının kullanımıyla bankacılık sektöründeki dalgalanmaların tespit edilmesi ve bununla berber doğacak müşteri taleplerine yönelik hizmet kalitesine doğru ve proaktif bir yaklaşımla karşılanması gerektiğine değinmiş.

Kıshada ve Diğerleri (2016). Çalışmalarında; Malezya'da İslami Bankacılık üzerinde kullanılan yapay zekâ teknolojisinin müşteri sadakatine olan etkisini incelemişler, 373 anket verisi kullanılarak yapay zekâ uygulamasının verilerinin doğruluğu incelenmiş yapılan analizlerle beraber 5-FCV tabanlı uygulamanın sonuçlarının doğruluğu tartışımıştır.

Patil ve Dharwadkar (2017). Yaptıkları deneysel çalışmada yapay zekâ tabanlı bankacııık uygulamalarıyla elde ettikleri veri setlerini iki sınıfa ayırmış, ilkinde dolandırıcılık ve kredi puanlarını ikincisinde ise müşteri kimliği, yaş, cinsiyet, bakiye, gelir, kredi olarak kart durumu, medeni durum, kredi türü, hesap türü, yaptığı işlem sayısı, eğitimi ve işi gibi kişisel verileri içerir. 1000 müşterinin kaydını incelendiği bu veri setinde ilk veri seti için \%78 ikinci veri seti içinse \%98 doğru veri analizi yapıldığı görülmüştür.

Ravi (2018). Çalışmasında yatırım bankacılı̆̆ında kullanılan yapay zekâ alt yapılı uygulamalarının; risk değerlendirmesi, finansal durum, değer katma, tutarlıık ve karar verme faktörlerini nasıl etkilendiğini tartışmıs bununla berber bankacılıkta kara para akışının bu uygulamalarla engellenebilirliğine değinmiştir.

Alzaidi (2018). Çalışmasında Ortadoğu ülkelerinde yapay zekâ kullanımının bankacılık sektörüne olan etkisini incelemiştir. 200 farklı banka çalışanından alınan verilerle çalışma oluşturulmuş elde edilen veriler sonucunda diğer bölgelere kıyasla Ortadoğu bankacılık sektörünün teknolojik gelişim hızının daha yavaş olduğuna değinilmiştir.

Payne ve diğerleri (2018). Çalışmalarında, yapay zekâ destekli cep şube uygulamasını ele almışlardır, 248 lisans öğrencisine uyguladıkları anket tekniği ile mobil bankacılık kanalıyla sunulan çevrimiçi destek hizmetlerinin önemine değinmiş ve bununla berber uygulamaların yetersiz olduğunu savunmuştur.

Kaplan (2018). Çalışmasında mobil bankacılık kanalı kullanımında güvenilirlik ilkesinin önemine değinmiş, kullanıcıların demografik özellikleri de göz önüne alınarak güvenilirlik faktörüyle ilişkisi incelenmiştir.

Shustova ve Blagoev (2018). Çalışmalarında Kazakistan örneği üzerinden, yapay zekâ tabanlı internet bankacılığı kanalının kurumsal ve bireysel bankacılıkta farklılı̆ına, dijital bankacılık kanalı için farklı ekipler kurulmasına, uygulamaların sade ve anlaşılabilir olması gerektiğine değinmiş bununla beraber bu uygulamalar çerçevesinde risk faktörünün belirlenmesinde bu uygulamaların etkin kullanımını tartışmıştır.

Ceran (2019) Çalışmasında Bankacılık sektöründe yapay sinir ağlarının kullanılmasıyla risk teşkil eden kredilerin belirlenmesi ve yönetilmesi konusuna değinilmiş bununla berber bu kullanımda güven faktörünün bankalar için önemine değinilmiştir.

Zınksa ve diğerleri (2019). Çalışmalarında, IVR sisteminde müşterinin ses analizi ile tanınmasının müşteri sadakati üzerine etkisine değinmiş bununla beraber interaktif bir bankacılık analizinde iletişimde verimliliğin IVR ile \%87 arttığını belirtmiştir.

Votintseva ve diğerleri (2019). Çalışmalarında Rusya Federasyonu'nun Dijital Ekonomi programı çerçevesinde araştırmasını 3 temel sınıfa ayırarak; finansal aktörlerin faaliyet bölgeleri, Etkili müşteri odaklı hizmet için platformlar ve teknolojiler ve bilgi platformlarının geliştirilmesi olarak belirlenmiş ve yapılan anket uygulaması yapmış, teknolojik bankacılık uygulamalarının dijital ülke ekonomilerine olan olumlu etkilerine değinmiştir.

Gümüş ve diğ., (2020) Yaptıkları çalışmalarında Türkiye'de bankaların yapay zekâ tabanlı alternatif dağıtım kanallarında yapılan işlemlere değinilmiş bununla birlikte yapay zekâ kullanımı ile demografik özellikleri arasında ki güven korelasyonu incelenmiştir.

Adamopoulou ve Moussiades (2020). Çalışmalarında, bankacılık uygulamaları için kullanılan Chat botlar üzerinde bir araştırma yapmış, müşterilerin Chat bot kullanımlarında güvenilirlik faktörünün Chat botların işlem setleri sırasında verebildiği cevapların günlük dile yakınlığıyla alakalı olduğunu tartışmıştır.

Singh ve Lin (2020). Çalışmalarında İngiltere örneği ile Kara Para Aklamanın Önlenmesi ve Terörle Mücadele için yapay zekâ tabanlı uygulamaların önemine değinmiş, Sahte ödemelerin, gizli bağış̧ıların, vergilerden kaçma ya da kaçınma gibi risklerin belirlenmesi, verilerin elde edilmesi ve bu suç gelirlerinin aklanmasına yönelik banka üzerinden yürütülen faaliyetlerin tespit edilmesi için yapay sinir ağları ile kurulan uygulamalara değinmiştir. 
Çelik ve Mangır (2020) Çalışmalarında Endüstri 4.0 kavramıyla beraber bankacılık sektöründe dijitalleşmeyi ele almış, bu süreçte yurt içi ve uluslararası alanda kullanılan alternatif bankacılık hizmet kanallarında kullanılan yazılım tabanlarına değinilmiştir.

\subsection{Bankacılık Sektöründe Kullanılan Yapay Zekâ Tabanlı Alternatif Hizmet Kanalları}

2020 yılı Türkiye Bankalar Birliği'nin açıkladığı istatistiksel veriler incelendiğinde; 34 adet mevduat, 14 adet yatırım ve kalkınma, 6 adet katııım bankası olmak üzere toplamda 54 banka yurt içinde faaliyet göstermektedir. Yine aynı bankalara ait verilerde toplam 186.612 banka çalışanı olduğu, toplamda 9.939 adet aktif şube ile bankacılık sektörünün hızla gelişen bir sektör olduğunu belirtebiliriz. Bu nedenle yurt içindeki bankalar da yine gelişen bu sektörde hem tutunma hem potansiyel müşterileri kazanabilme hem de çağa uyum sağlamak adına teknoloji kullanımlarını artırmış ve bu kapsamda yapay zekâya yönelim de artmıştır (Türkiye Bankalar Birliği, https://www.tbb.org.tr/tr ).

Kaur vd., 2017’ye göre yapay zekâ tabanlı hizmet kullanımının faydalarını şöyle sıralayabiliriz;

- Yapay zekâ tabanlı uygulamalar birden fazla müşteriye aynı anda hizmet verebilir.

- Kullanıcı davranışlarını takip ederek sınıflandırabilir

- Kişiselleştirilmiş harcama ve tasarruflar sunabilir

- Finansal ipuçları ve öngörüleri aktarabilir

- Kişisel sanal asistanlar sayesinde kullanıcılarla iletişime geçebilir

- Para transferi, ödemeler gibi seçeneklerle kullanıcıları yönlendirerek finansal planlamalarda yardımcı olabilir.

- Makine öğrenme sistemi ile dolandırıcılık işlemlerinin tespit edilmesi süreçlerinde yapay zekâdan yararlanılabilir.

\subsubsection{Mobil Bankacılık Kanalı}

Teknolojinin gelişimiyle hizmet üretimlerinde çevrimiçi uygulamalar daha yaygın hale gelmeye başlamıştır. Tüketicilerin gün geçtikçe daha fazla tercih ettiği çevrimiçi uygulamalar bankaları da dijitalleşmeye yöneltmiştir. Mobil bankacııık ise kullanıcıların bankalardaki ürünlerine telefonları aracılığıyla bir aplikasyon üzerinden ulaşmalarına olanak sağlayan bir etkileşimdir (Laukkanen, 2017:1042).

Tüketicilerin çevrim içi uygulamaları gün geçtikçe tercih etmesiyle beraber mobil bankacılığa olan talep ve yönelim de bir o kadar artmıştır, var olan müşterilerin kaybedilmemesi ve potansiyel müşterilerin kazanılması için mobil uygulama hizmetlerinin kaliteli hizmet sunması önemli hale gelmiştir. Bankacılık sektöründe müşteri deneyim ofisleri ile müşteri beklentilerine cevap verebilmek için daha kaliteli hizmet çerçevesinde müşteri deneyiminin iyileştirilmesi ve pazar rekabetinde avantaj elde edebilirler (Doğan ve Burucuoğlu, 2018: 1193).

Mobil bankacılık uygulamalarının; kişiselleştirilebilir menüleriyle kullanıcıların uygulamayı özelleştirebilmesi, sürekli kullanılan uygulamalarının ana ekranlara eklenmesi, NFC ya da QR kod sistemlerine entegre olmaları, bununla beraber Chat bot desteği ile sesli ve yazılı iletişim kurabilmeleri, sanal asistanlarla uyumlanmaları mobil bankacılık kanallarının teknolojiye uyum sağlayabilme bununla beraber kullanıcılara kaliteli ve hızlı bir hizmet sunmak için gerekli bir alternatif dağıtım kanalı olduğu görülmüştür (Yavuz ve Babuşçu, 2018: 33).

Türkiye'de faaliyet gösteren yatırım, kalkınma ve katılım bankalarının 1958 yılından beri Türkiye Bankalar Birliği'ne üye olmaları zorunludur. Türkiye Bankalar Birliği her yıl mart, haziran, eylül ve aralık ayı olmak üzere dört farkı zaman diliminde üye bankalara ait verileri yayımlamaktadır, bu veriler bankaların ekonomideki yeri, bankaların personel ve fiziki verilerine dayanmakla beraber bankaların dijitalleşme sürecinde kullandığı verileri de içermektedir. 2016-2020 yılları arasında Türkiye Bankalar Birliği Verilerine göre bu kanal üzerinden yapılan işlemler aşağıdaki gibidir;

- Kredi kartı başvurusu, ek kart başvurusu, kredi başvuruları, Fatura ödemeleri, fatura ödeme talimatları vermek gibi finansal olmayan işlemler,

- Vergi, prim, kredi kartı, ceza, kredi ve şans oyunları için yapılan ödemeler,

- Havale, EFT ve virman işlemlerini kapsayan para transferleri,

- Hisse senedi, fon, vadeli hesap işlemleri, altın işlemleri, ViOP ve Tahvil- Bono yatırımlarını kapsayan yatırımlar 
- Hesapları Yönetme

- Avans ve ödemeler ile kredi kartı işlemleri

- Diğer Finansal İşlemler

Yine TBB aracılığıyla alınan 2016 - 2020 yılları arasında mobil bankacılık kanalı üzerinden, bireysel ve kurumsal aktif kullanıcı sayısı ve yapılan işlemler şöyledir;

- 2016 yılında bireysel mobil bankacılık kanalında toplamda 62.999.259 aktif kullanıcı tarafından; 5.514 .744 adet finansal olmayan işlem, 189.873 adet para transferi, 167.820 adet ödeme, 27.034 adet yatırım, 66.868 adet kredi kartı işlemi ve son olarak 16.431 adet diğer finansal işlemler olmak üzere toplamda 5.982 .770 adet işlem gerçekleşmiştir. Kurumsal olaraksa; toplamda 1.998.494 aktif kullanıcı tarafından; 235.160 adet finansal olmayan işlem, 20.374 adet para transferi, 3.460 adet ödeme, 693 adet yatırım, 1.841 adet kredi kartı işlemi ve son olarak 319 adet diğer finansal işlemler olmak üzere toplamda 1.998.494 adet işlem gerçekleşmiştir.

- 2017 yılında ise; bireysel mobil bankacılıkta 99.915 .216 adet aktif kullanıcl; 8.608 .618 adet finansal olmayan işlem, 350.632 adet para transferi, 291.154 adet ödeme, 45.872adet yatırım, 116.929 adet kredi kartı işlemi ve son olarak 46.627 adet diğer finansal işlemler olmak üzere toplamda 9.459 .832 adet işlem gerçekleşmiştir. Kurumsal olaraksa; toplamda 2.928.027 aktif kullanıcı tarafından; 461.756 adet finansal olmayan işlem, 35.265 adet para transferi, 6.305 adet ödeme, 1.375 adet yatırım, 3.306 adet kredi kartı işlemi ve son olarak 562 adet diğer finansal işlemler olmak üzere toplamda 508.569 adet işlem gerçekleşmiştir.

- 2018 yılında ise; bireysel mobil bankacılıkta 102.887 .626 adet aktif kullanıcı; 12.586 .391 adet finansal olmayan işlem, 500.448 adet para transferi, 413.034 adet ödeme, 100.343 adet yatırım, 180.539 adet kredi kartı işlemi ve son olarak 118.248 adet diğer finansal işlemler olmak üzere toplamda 13.899 .003 adet işlem gerçekleşmiştir. Kurumsal olaraksa; toplamda 4.156 .495 aktif kullanıcı tarafından; 456.488 adet finansal olmayan işlem, 53.471 adet para transferi, 9.379 adet ödeme, 2.541 adet yatırım, 5.690 adet kredi kartı işlemi ve son olarak 308 adet diğer finansal işlemler olmak üzere toplamda 527.877 adet işlem gerçekleşmiştir

- 2019 yılında; bireysel mobil bankacılıkta 175.320 .217 aktif kullanıcı; 12.628 .632 adet finansal olmayan işlem, 706.386 adet para transferi, 54.817 adet ödeme, 123.511 adet yatırım, 239.584 adet kredi kartı işlemi ve son olarak 192.498 adet diğer finansal işlemler olmak üzere toplamda 14.438 .790 adet işlem gerçekleşmiştir. Kurumsal olaraksa; toplamda 5.540.187 aktif kullanıcı tarafından; 528.654 adet finansal olmayan işlem, 70.973 adet para transferi, 14.384 adet ödeme, 3.712 adet yatırım, 8.355 adet kredi kartı işlemi ve son olarak 1.211 adet diğer finansal işlemler olmak üzere toplamda 627.289 adet işlem gerçekleşmiştir

- 2020 yılında; bireysel mobil bankacılıkta 224.691 .000 aktif kullanıcl; 16.504 .100 adet finansal olmayan işlem, 1.106.114adet para transferi, 760.728 adet ödeme, 241.148 adet yatıım, 330.429 adet kredi kartı işlemi ve son olarak 234.768 adet diğer finansal işlemler olmak üzere toplamda 19.177.287 adet işlem gerçekleşmiştir. Kurumsal olaraksa; toplamda 7.767.000 aktif kullanıcı tarafından; 212.700 adet finansal olmayan işlem, 89.078 adet para transferi, 18.327 adet ödeme, 4.245 adet yatırım, 10.504 adet kredi kartı işlemi ve son olarak 803 adet diğer finansal işlemler olmak üzere toplamda 335.657 adet işlem gerçekleşmiştir.

TBB'den alınan verilerle bireysel ve kurumsal kullanıcı sayıları ile işlem adetleri verilerinden aşağıdaki grafikler oluşturulmuştur. Aşağıdaki grafikler; aktif kullanıcı sayısı (I.B.K.S), Finansal olmayan işlemler. (F. Olm. İşı.) Para transferleri (Para Tr), ödemeler, kredi kartı işlemleri (KK İşl.) ve diğer finansal işlemler (Diğg. Fin. İşı.) işlem âdeti (Milyon) yer almıştır.

\section{Grafik 1. Bireysel Mobil Bankacilık Verileri}




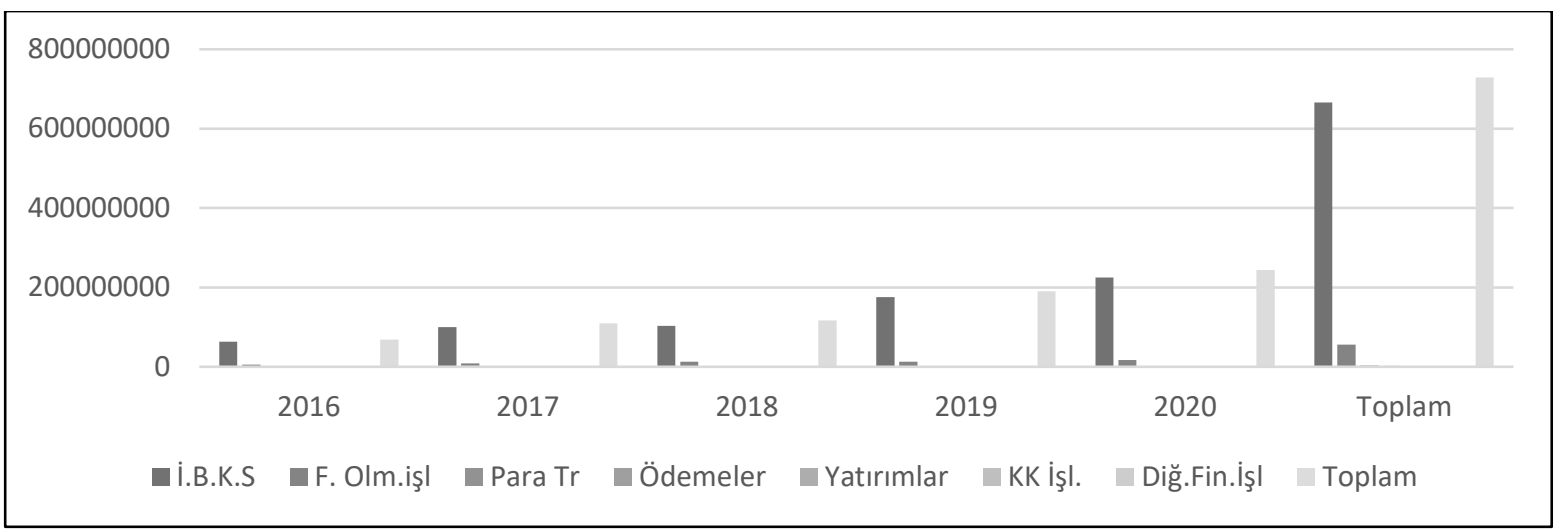

Grafik incelendiğinde; kalemler özelinde yıl bazlı değişimler olsa da genel olarak mobil bankacılık kanalında hem kullanıcı sayısı hem de işlem âdeti olarak bir artış olduğu gözlemlenebilmektedir. İşlem kalemlerinde en çok artışın Finansal olmayan diğer işlemler (Düzenli fatura ödeme talimatları, kredi başvuruları, kredi kartı başvuruları) olduğu gözlemlenmiştir. Mobil uygulamaların cep telefonu üzerinden ulaşılabilen bir kanal olması ve birçok işlemi yapay zekâ tabanıyla hızlıca yapabilmesini bu artışın nedeni olarak gösterilebilir.

\section{Grafik 2. Kurumsal Mobil Bankacılık Verileri}

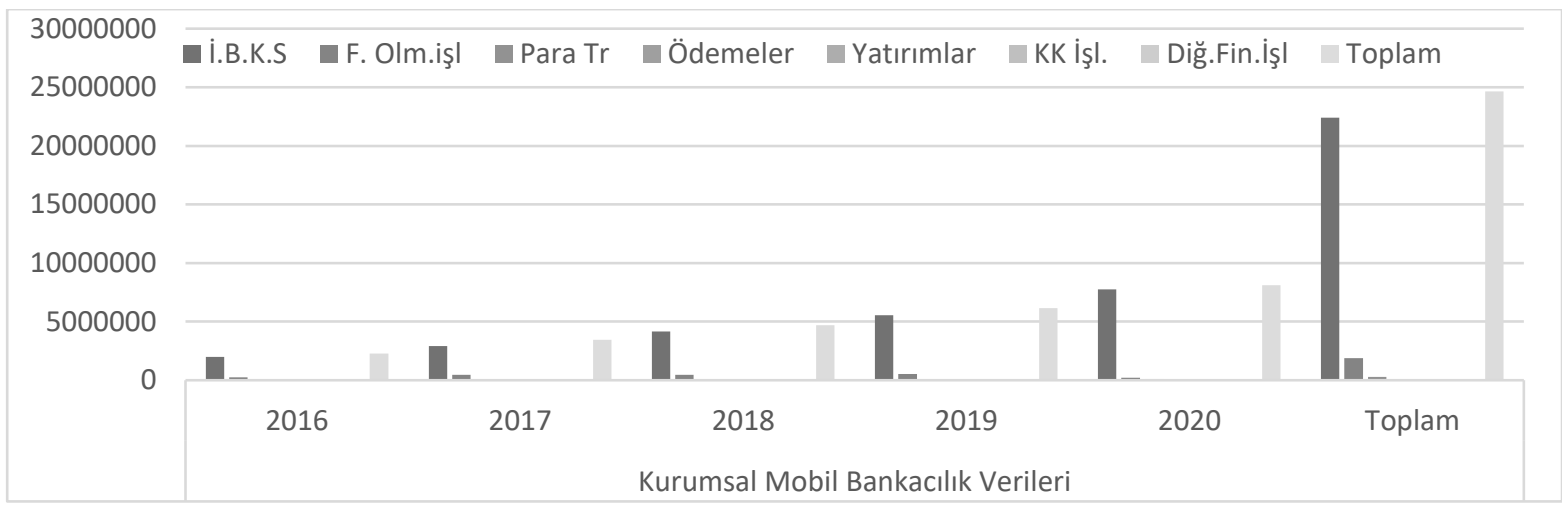

Kurumsal mobil bankacılık kanalı verileri incelendiğinde bireysel kullanımda olduğu gibi genel bir atış gözlemlenmiştir bununla beraber kurumsal kullanımlarda artış hızının bireyselden daha düşük olduğu görülmüştür, Merkez Bankası'nın işlem ücret politikası ve limit kısıtlarının bu artış hızı farklılı̆̆ına neden olduğu söylenebilir.

\subsubsection{Internet Bankacilık Kanalı}

Teknolojik ilerlemenin bankacılık sektörüne yansımalarıyla alternatif dağıtım kanallarından birisi de internet bankacılığı olmuştur. Internet bankacılığını kavram olarak ifade etmek istersek banka müşterilerinin bir tarayıcı üzerinden internet ağları aracılığıyla bankacılık ürünlerini kontrol edebildiği bir sistemdir. Gelişen teknolojilerle birlikte bankacılık sektöründe pazar dengeleri de değişmiş; tutundurma, potansiyel müşterileri kazanabilme, var olan müşteri kitlesini kaybetmeme ve kampanya/ürün dağıtımları için alternatif kanallara yönelim gereklilik haline gelmiştir (Ustasüleyman ve Eyüboğlu, 2021: 12)

Internet bankacılığı müşteri taleplerini üç başlık altında karşılar ilki banka ürün ve hizmetlerine kullanıcı verilerinin eşleşmesiyle tamamlanan bilgi adımı, ikincisi müşterinin banka ile irtibata geçtiği ve kredi/Kredi kartı ya da diğer ürün başvuruları, şikâyet ve önerilerin gibi taleplerin iletilebildiği ve bu süreçte Chat bot gibi yapay zekâ tabanlı uygulamaları doğrudan kullandığı iletişim süreci ve son olarak da müşterilerin para transferi, ödemeler ve yatırım gibi eylemleri doğrudan gerçekleştirebildikleri İşlem adımıdır (Özcan, 2007: 77-78).

Türkiye Bankalar Birliği'nden alınan son 5 yıla ait bireysel ve kurumsal bankacılık aktif kullanıcı sayısı ve işlem adetleri aşağıdaki gibidir;

- 2016 yılında bireysel internet bankacılık kanalında toplamda 70.727.120 aktif kullanıcı tarafından; 2.345.234 adet finansal olmayan işlem, 156.878 adet para transferi,137.797 adet ödeme, 35.900 adet yatırım, 43,256 adet kredi kartı işlemi ve son olarak 11.746 adet diğer finansal işlemler olmak üzere toplamda 2.730 .811 adet işlem gerçekleşmiştir. Kurumsal olaraksa; toplamda 5.155.006 aktif kullanıcı tarafından; 884.140 adet finansal olmayan işlem, 
127.467 adet para transferi, 44.814 adet ödeme, 6.033 adet yatırım, 5.241 adet kredi kartı işlemi ve son olarak 2.853 adet diğer finansal işlemler olmak üzere toplamda 1.070 .548 adet işlem gerçekleşmiştir.

- $\quad 2017$ yılında ise; bireysel internet bankacılık kanalında 48.029 .787 adet aktif kullanıcl; 2.551 .313 adet finansal olmayan işlem, 134.006 adet para transferi, 110.740 adet ödeme, 40.753 adet yatırım, 38.873 adet kredi kartı işlemi ve son olarak 9.414 adet diğer finansal işlemler olmak üzere toplamda 2.885.099 adet işlem gerçekleşmiştir. Kurumsal olaraksa; toplamda 4.996.039 aktif kullanıı tarafından; 846.985 adet finansal olmayan işlem, 138.626 adet para transferi, 45.763 adet ödeme, 5.965 adet yatırım, 4.803 adet kredi kartı işlemi ve son olarak 2.848 adet diğer finansal işlemler olmak üzere toplamda 1.044 .990 adet işlem gerçekleşmiştir.

- 2018 yılında ise; bireysel internet bankacılık kanalında 46.662 .664 adet aktif kullanıcl; 2.407 .510 adet finansal olmayan işlem, 128.921 adet para transferi, 99.497 adet ödeme, 46.938 adet yatırım, 30.588 adet kredi kartı işlemi ve son olarak 10.390 adet diğer finansal işlemler olmak üzere toplamda 2.723 .844 adet işlem gerçekleşmiştir. Kurumsal olaraksa; toplamda 5.133.314 aktif kullanıı tarafından; 923.120 adet finansal olmayan işlem, 142.318 adet para transferi, 56.959 adet ödeme, 6.206 adet yatırım, 5.264 adet kredi kartı işlemi ve son olarak 2.653 adet diğer finansal işlemler olmak üzere toplamda 1.136 .520 adet işlem gerçekleşmiştir

- 2019 yılında; bireysel internet bankacilık kanalında 42.662 .664 aktif kullanıcl; 1.890 .245 adet finansal olmayan işlem, 127.640 adet para transferi, 85.061 adet ödeme, 41.766 adet yatırım, 26.587 adet kredi kartı işlemi ve son olarak 10.886 adet diğer finansal işlemler olmak üzere toplamda 2.182.185 adet işlem gerçekleşmiştir. Kurumsal olaraksa; toplamda 5.102.014 aktif kullanıı tarafından; 975.265 adet finansal olmayan işlem, 133.472 adet para transferi, 39.548 adet ödeme, 5.943 adet yatırım, 4.398 adet kredi kartı işlemi ve son olarak 2.887 adet diğer finansal işlemler olmak üzere toplamda 1.161 .513 adet işlem gerçekleşmiştir.

- 2020 yılında; bireysel internet bankacılık kanalında 44.655 .000 aktif kullanıcl; 1.318 .000 adet finansal olmayan işlem, 997.590 adet para transferi, 73.869 adet ödeme, 67.041 adet yatıım, 23.223 adet kredi kartı işlemi ve son olarak 12.237 adet diğer finansal işlemler olmak üzere toplamda 2.491 .960 adet işlem gerçekleşmiştir. Kurumsal olaraksa; toplamda 5.368.000 aktif kullanıcı tarafından; 1.116 .000 adet finansal olmayan işlem, 126.610 adet para transferi, 36.016 adet ödeme, 5.900 adet yatırım, 3.675 adet kredi kartı işlemi ve son olarak 3.055 adet diğer finansal işlemler olmak üzere toplamda 1.342.256 adet işlem gerçekleşmiştir.

Aşağıdaki grafikler Türkiye Bankalar Birliği tarafından dört ay aralıklı yayımlanmış ve ortalama 24 bankanın son beş yıla ait bireysel ve kurumsal internet bankacııık kullanım verileriyle hazıllanmıştır. İgili grafikler verilerin internet bankacılığı üzerinden gerçekleştirilen; Finansal olmayan işlemler (F. Olm. İşı.) Para transferleri (Para Tr), ödemeler, kredi kartı işlemleri (KK İşI.), diğer finansal işlemler (Diğ. Fin. İşı.) ve aktif kullanıcı sayısı (i. B.K.S) işlem âdeti (Milyon) yer almıştır.

\section{Grafik 3. Bireysel İnternet Bankacılık Verileri}

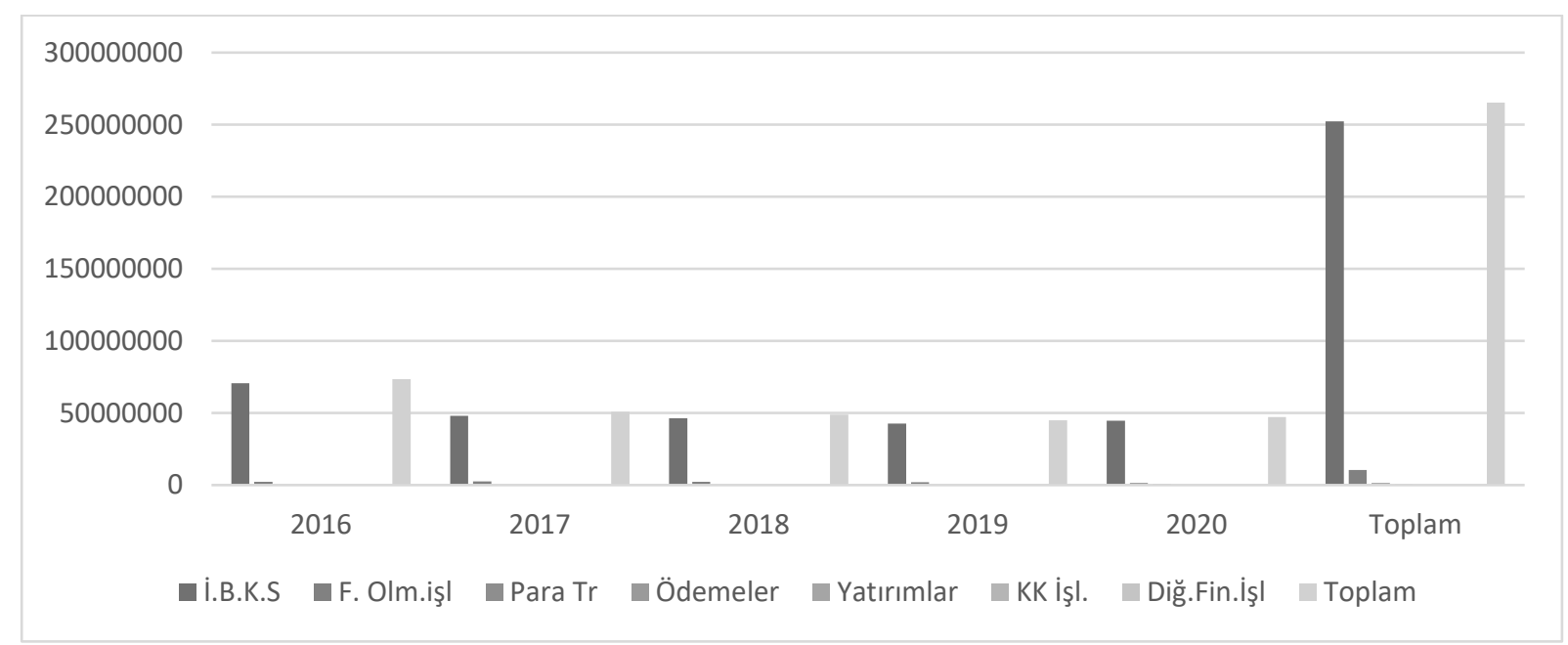

Bireysel internet bankacılık kanalı verileri incelendiğinde toplam kullanıcı ve işlem sayısında yıl bazlı artışlar olduğu görülse de finansal ve finansal olmayan işlemler üzerinde giderek artan bir azalma gözlemlenebilir, azalış yılları incelendiğinde yine aynı yılların mobil bankacılık verilerinin artışa geçtiği dönemlere denk geldiği görülebilmektedir bu verilerle akıllı telefon ve daha fonksiyonel yapay zekâ (QR Kod- NFC- Mobil Ödeme) entegrasyonu internet bankacılığının önüne geçtiği düşünülmektedir. 


\section{Grafik 4. Kurumsal İnternet Bankacılık Kullanım Verileri}

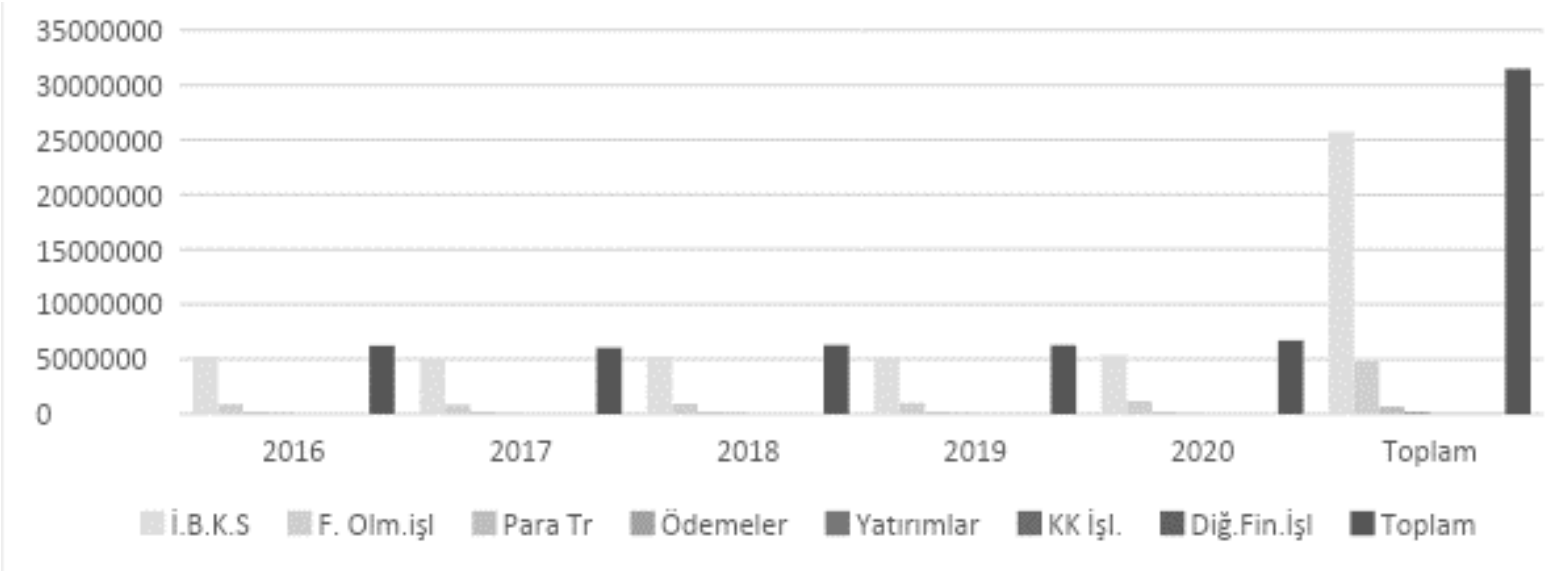

Kurumsal İnternet bankacılık verileri incelendiğinde yine kullanıc sayısının bireysel internet bankacılığına göre daha az olduğu görülebilir bununla beraber bireysel internet bankacılığı işlem adetlerindeki azalma kurumsal internet bankacılığında gözlemlenmemektedir, yıl bazında kullanım sayıları hemen hemen aynı adet düzeyinde seyretmektedir.

\subsubsection{IVR/IVN Dailer Verileri}

Etkileşimli sesli yanıt sistemi (IVR- Interactive Voice Responce) bilinen sesli yanıt sistemlerinin aksine bir ana bilgisayar ağına bağlı, ses tanıma ve ağ arayüzü ile desteklenebilen bir sistemdir. Yeni nesil IVR teknolojisi gelen aramaları segmentler, arama yoğunluğu, arama sebebi ve aranan ürün türüne göre sınıflandırarak işlemleri tuşlama komutu ile tamamlayan ya da aktarılması gereken durumlarda ilgili birime yönlendirme yapabilen bununla beraber gelen aramaları numaralar üzerinden inceleyerek gerektiği durumlarda numaraları engelleyebilen ya da doğrudan görüşmeleri sonlandırabilen yeteneklere sahip bir sistemdir. IVR sistemleri gelen çağrılara öncelikle arayan kişiden bilgi talep eder ve güvenlik aksiyonunu tamamlar, çağrıda işlemini yine sesli olarak talep eder ve işlem menüsünde doğru başlıklara yönlendirerek sesli onayla alıp işlemleri tamamlayabilir gereken durumlarda görüşmeyi aktarır (Inceoğlu, 2004).

Akıllı Dış Arama Sistemi (IVN- Interactive Voice Notification) ise IVR sistemini dış arama yapabilme yeteneğine sahip modelidir. Operatör olmadan aynı anda birden fazla arama yapabilen, metinleri sesli hale dönüştürebilen, tuşlama yöntemi ile güvenlik süreçlerini tamamlayabilen ve rapor sunabilen bir algoritmadır (https://tr.asseco.com). sıralayabiliriz.

Küçükdurmaz’a (2014) göre; Sesli yanıt sistemleri ile müşterilerin yapabileceği başlıca işlemleri aşağıdaki gibi

- Hesap bilgilerini öğrenme

- $\quad$ Kredi kartı borç bilgisi ve ödemesi

- Para transferleri ile ilgili bilgi edinme

- Ödemeler Ajandasını takip edebilme

- E Posta üzerinden dekont alabilme

- Fatura Ödemeleri

- Şifre işlemleri

Türkiye Bankalar Birliği'nin son 5 yıllık verilerine göre 2016 yılında 99.285 .661 adet, 2017 yılına 94.966 .000 adet, 2018 yılında 91.100 .000 adet, 2019 yılında 81.100 .000 adet, son olarak 2020 yılında 69.900 .000 adet olmak üzere toplamda 287.971.600 adet işlem gerçekleşmiş ve bu veriler; mart, haziran, eylül ve aralık ayı dağılımlarına göre grafik haline getirilmiştir.

Aşağıdaki grafik, ortalama 24 bankanın son 5 yılda dörder aylık yayımladığı verilerden elde edilmiştir. Bu tabloya göre banka müşterilerinin çağrı merkezlerinde IVR ve IVN ile yaptığı görüşmeler milyon cinsinden belirtilmiştir.

\section{Grafik 5. IVR-IVN Verileri}




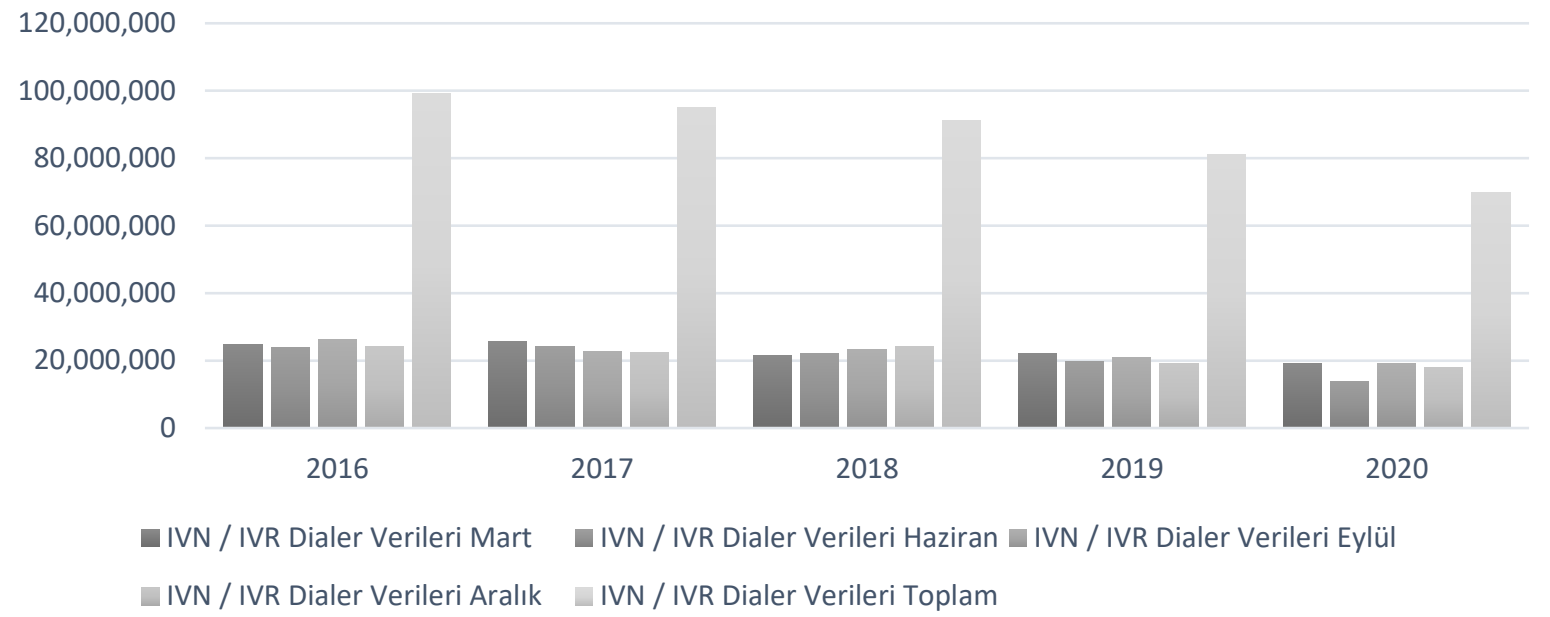

IVR/IVN grafiği incelendiğinde düzenli bir seyirde azalış görülmektedir, ilerleyen teknolojiyle birlikte daha fonksiyonel dağıtım kanalları olan internet bankacılığı ve mobil bankacılık kanallarının bir önceki grafiklerde incelenmesi ile görülebilen artış düzeyine paralel olarak, daha az özellik bulunduran IVR/IVN kanallarının kullanımında azalış gözlemlenmiştir.

\section{Sonuç}

Endüstri 4.0 sürecinde birden fazla bileşen birçok sektör için bir değişim aracı ve ölçütü olarak tanımlanabilir. Dördüncü sanayi devriminin bileşenlerinden birisi olan yapay zekâ bileşeni de günümüzde birçok alanda kullanılmakta ve giderek daha fazla gelişmektedir.

Bankacılık sektörü ülke ekonomileri için oldukça önemli finansal kuruluşlardır, bu kuruluşların para akışını sağlanması ve fonlama işlemleriyle beraber bir de finansal aracılık görevi vardır. Bankalar üzerinden devam eden hem uluslararası hem yurt içi nakit sirkülasyonu ekonomide olduğu kadar terörizmin finansal ayağı ve suç gelirlerinin aklanmasında önemli bir faktördür. Geliştirilen yapay zekâ uygulamalarıyla bu suç etmenlerinin de önüne geçilmeye çalışıldığı görülmektedir.

Yapılan çalışmalarla, bankaların dijitalleşme sürecinde yapay zekâ uygulamalarına yönelmeleri maliyet kavramı olarak değerlendirildiğinde olumlu sonuçlar edinilmiş ve akıllı sınıflandırılmalar sayesinde müşterilere yönelik uygun ürünlerin tespiti daha hızlı yapılmış ve en doğru kanal aracııı̆ıyla sunularak hizmet kalitesinde artış hedeflenmiştir.

Türkiye Bankalar Birliği'nden elde edilen verilerle Türkiye'de faaliyet gösteren bankaların dijital verileri incelendiğinde son beş yılda müşteri tercihlerinin kolay ulaşılabilir ve iletişim kurabildikleri mobil bankacılık kanalı olduğu görülebilir, birden fazla yapay zekâ destekli uygulamayı barındıran bu kanal akıllı telefonlar aracılığıyla bankalara en hızlı ulaşım aracı olarak adlandırılabilir.

Yine aynı veriler internet bankacılığı hem işlem tutarı limitlerinin fazlalığı hem de yapay zekâ destekli uygulamaların varlığıyla tercih edilen bir kanaldır, IVR-IVN kanalları ise müşterilerle doğrudan sesli iletişim kurabilen ve yönlendiren bir sistem olduğu için yine hem bankaların hem de müşterilerin işlemlerini sürdürmeyi tercih ettiği bir kanal olsa da bu iki alternatif kanalın yıllar içerisinde mobil şube gelişimiyle kullanımlarında azalma olduğu görülmektedir, yani kullanıııların tercihinin yapay zekâ fonksiyonu yüksek olan kanalı tercih ettiğini gözlemleyebiliriz.

Son olarak ödemeler, transferler ve yatırımlar gibi günlük yaşamda hem bireysel hem de kurumsal olarak birden çok kez gerçekleştirilen işlemler, bankaları teknolojik gelişmeleri daha sıkı takip etmeye yöneltmiş bununla beraber kullanıcıları da teknolojiyle bütünleştrmiştir tüm bu etkileşimler aynı zamanda toplum 5.0 sürecine de katkı sağlayacak ve teknoloji okur-yazarlı̆ı̆na olumlu etkisi olacaktır.

\section{Kaynakça}

Adamopoulou, E. Ve Moussiades, L. (2020, Haziran). Chatbot Teknolojisine Genel Bakış. In Yapay Zekâ Uygulamaları Ve Yenilikler Ifıp Uluslararası Konferansı (S. 373-383). Springer, Cham.

Aggarwal, M. (2011). Bilgi Erişim Ve Soru Cevaplama Nıp Yaklaşımı: Bir Yapay Zekâ Uygulaması. International Journal Of Soft Computing And Engineering (ljsce), 1 (Ncal2011). 
Akalın, B., \& Veranyurt, Ü. (2020). Sağlık Hizmetleri Ve Yönetiminde Yapay Zekâ. Acta Infologica, 5(1), 5-6.

Akbaba, A. İ., \& Özdemir, A. (2013) Küçük Ve Orta Ölçekli İşletmelerin (Kobi'lerin) Pazarlama Faaliyetlerinde Bilgi ve iletişim Teknolojilerinin Kullanımı Ve Bir Uygulama. Https://Www.Researchgate.Net/Publication/265251894 (Erişim Tarihi 25.04.2021)

Altinirmak, S., \& Karamaşa, Ç. (2016). Comparıson Of Machıne Learnıng Technıques For Analyzıng Banks'fınancıal Dıstress. Balıkesir Üniversitesi Sosyal Bilimler Enstitüsü Dergisi, 19(36), 291-304.

Alzaidi, A. A. (2018). Impact Of Artificial Intelligence On Performance Of Banking Industry in Middle East Ocr. International Journal Of Computer Science And Network Security, 18(10), 140-148.

Artar, O., \& Türkay, U. İ. (2021). Havacılık Sektöründe Havalimanlarının Dijital Dönüşümü. Working Paper Series, 2(1), 86-97.

Ateş, E. (2019). Derin Öğrenme İle Sesli Komut Tanıma (Master's Thesis, Esogü, Fen Bilimleri Enstitüsü).

Bahar, M., Yüzbaşıoğlu, N., \& Topsakal, Y. (2019). Akıllı Turizm Ve Süper Akıllı Turist Kavramları Işığında Geleceğin Turizm Rehberliğine Bakış. Journal Of Travel And Tourism Research, (14), 72-93.

Bilal Zorić, A. (2016). Predicting Customer Churn İn Banking İndustry Using Neural Networks. Interdisciplinary Description Of Complex Systems: Indecs, 14(2), 116-124.

Ceran, M. (2019). Bankacılıkta Dijitalleşme Kapsamında, Öğrenen Yapay Zekâ Desteğiyle Sorunlu Kredilerin Belirlenmesi Marmara Üniversitesi Bankacılık Ve Sigortacılık Enstitüsü Bankacılık Anabilim Dalı. Yayınlanmış Doktora Tezi

Çelik, S. B., \& Mangır, F. (2020). Bankacılık Sektörünün Dijitalleşmesi: Dünyada Ve Türkiye'de Durum Analizi. Cyberpolitik Journal, 5(10), 260-282.

Çelik, S. B., \& Mangır, F. (2020). Bankacılık Sektörünün Dijitalleşmesi: Dünyada Ve Türkiye'de Durum Analizi. Cyberpolitik Journal, 5(10), 260-282.

Demirkol, F. (2020). Ulusal Güvenlikte Yapay Zekâ Kullanımı: Abd Ve Çin Örnekleri. İstanbul Gelişim Üniversitesi Sosyal Bilimler Dergisi, 7(2), 421-423.

Doğan, H., \& Burucuoğlu, M. (2018). Tüketicilerin Mobil Bankacılık Hizmet Kalitesi Algıları Ve Tekrar Kullanma Niyetleri: Ampirik Bir Araştırma. Uluslararası Yönetim İktisat Ve İşletme Dergisi, 14(4), 1183-1198.

G. Karagöz Ve C. Demiroğlu, "Etkileşimli Sesli Yanıt Çağrı Akışında Gramer Tabanlı Bir Türkçe Konuşma Tanıma Sisteminin Gösterilmesi," 2012 20. Sinyal İşleme Ve iletişim Uygulamaları Konferansı (SIu) , 2012, Ss. 1-2, Doi : 10.1109 / Siu.2012.6204849.

Gacar, A. (2019). Yapay Zekâ Ve Yapay Zekânın Muhasebe Mesleğine Olan Etkileri: Türkiye'ye Yönelik Fırsat Ve Tehditler. Balkan Sosyal Bilimler Dergisi, 8, 389-394.

Gencer, A. H. (2017). Yapay Sinir Ağları Ile Bitcoin Fiyatını Tahminleme Forecasting The Bitcoin Price Via Artificial Neural Networks.

Gunning, D. (2017). Açıklanabilir Yapay Zeka (Xai). Savunma Ileri Araştırma Projeleri Ajansı (Darpa), Nd Web, 2 (2).

Güçlüay, S. (2001). Orta Çağda Ticari Müesseseler (Bankalar, Birlikler, Şirketler). Fırat Üniversitesi Sosyal Bilimler Dergisi, 11(2), 295-304.

Gümüş, E., Medetoğlu, B., \& Tutar, S. (2020). Finans Ve Bankacılık Sisteminde Yapay Zekâ Kullanımı: Kullanıcılar Üzerine Bir Uygulama. Bucak Iş̧letme Fakültesi Dergisi, 3(1), 28-53.

Inceoglu, M. M. (2004). Bir Eğitim Kurumu Iç̧in Etkileşimli Sesli Yanıt Sistemi. Tojet: The Turkish Online Journal Of Educational Technology 3(2).

Iş̧ler, B., \& Kılıç, M. Eğitimde Yapay Zekâ Kullanımı Ve Gelişimi. Yeni Medya Elektronik Dergisi, 5(1), 1-11.

Kaplan, H. E. (2018). Mobil Bankacılık Kullanım Niyeti Ve Davranışında Birleştirilmiş Teknoloji Kabul Ve Kullanım Teorisi2 Ve Güven Faktörlerinin Etkisinin Araştırılması. 
Karaatlı, M., Helvacıoğlu, Ö. C., Ömürbek, N., \& Tokgöz, G. (2012). Yapay Sinir Ağlari Yöntemi ille Otomobil Satiş Tahmini. Uluslararası Yönetim İktisat Ve İşletme Dergisi, 8(17), 87-100.

Karakuş, C., \& Katman, F. (2019). Male Sınıfı Insansız Hava Aracı (iha) Teknolojisi Ve Konvansiyonel (Geleneksel) Savaştaki Yeri. Akademik Tarih Ve Düşünce Dergisi, 6(2), 882-897.

Kaur, D., Sahdev, S. L., Sharma, D., \& Siddiqui, L. (2020). Banking 4.0: 'The Influence Of Artificial Intelligence On The Banking Industry \& How Al Is Changing The Face Of Modern Day Banks'. International Journal Of Management, 11(6).

Kazu, I. Y., \& Özdemir, O. (2009). Öğrencilerin Bireysel Özelliklerinin Yapay Zekâ ïle Belirlenmesi (Bulanık Mantık Örneği). Akademik Bilişim, 11-13.

Keleş, A., Keleş, A., \& Akçetin, E. (2017). Pazarlama Alanında Yapay Zekâ Kullanım Potansiyeli Ve Akılı Karar Destek Sistemleri. Electronic Turkish Studies, 12(11).

Kıshada, Z. M., Wahab, N. A., \& Mustapha, A. (2016). Customer Loyalty Assessment In Malaysıan Islamıc Bankıng Usıng Artıficial Intellıgence. Journal Of Theoretical \& Applied Information Technology, 87(1).

Kuş̧̧u, E. (2015). Çeviride Yapay Zekâ Uygulamaları. Atatürk Üniversitesi Kazım Karabekir Eğitim Fakültesi Dergisi, (30), 45-58.

Küçük, D., \& Arıcı, N. (2018). Doğal Dil İşlemede Derin Öğrenme Uygulamalari Üzerine Bir Literatür Çalişmasi. Uluslararası Yönetim Bilişim Sistemleri Ve Bilgisayar Bilimleri Dergisi, 2(2), 76-86.

Küçükdurmaz, U. (2014). Effects Of Recent Ivr Applications On Call Center Performance in Banking Sector (Doctoral Dissertation, Graduate School Of Natural And Applied Sciences).

Laukkanen, T. (2017). Mobil Bankacilık. International Journal Of Bank Marketing

Ortiz, J., Marin, A., \& Gualdron, O. (2016). Implementation Of A Banking System Security in Embedded Systems Using Artificial İntelligence. Advances In Natural And Applied Sciences, 10(17), 95-102.

Öztemel, E. (2003). Yapay Sinir Ağları. Papatyayayincilik, Istanbul.

Öztürk, K., \& Şahin, M. E. (2018). Yapay Sinir Ağları Ve Yapay Zekâ 'ya Genel Bir Bakış. Takvim-i Vekayi, 6(2), 25-36.

Patil, P. S., \& Dharwadkar, N. V. (2017, February). Analysis Of Banking Data Using Machine Learning. In 2017 International Conference On I-Smac (Iot In Social, Mobile, Analytics And Cloud)(I-Smac) (Pp. 876-881). leee.

Payne, E. M., Peltier, J. W., \& Barger, V. A. (2018). Mobile Banking And Aı-Enabled Mobile Banking: The Differential Effects Of Technological And Non-Technological Factors On Digital Natives' Perceptions And Behavior. Journal Of Research in Interactive Marketing.

Pirim, A. G. H. (2006). Yapay Zekâ. Journal Of Yaşar University, 1(1), 81-93.

Ravi, H. (2018). Application Of Artificial İntelligence In İnvestment Banks. Review Of Economic And Business Studies, (22), 131-136.

Shustova, E., \& Blagoev, V. (2018). Risk Management in The Internet Banking: The Case Of Kazakhstan. Economic Studies, 27(5).

Singh, C., \& Lin, W. (2020). Can Artificial İntelligence, Regtech And Charitytech Provide Effective Solutions For AntiMoney Laundering And Counter-Terror Financing İnitiatives in Charitable Fundraising. Journal Of Money Laundering Control.

Soyhan, I., Gurel, S., \& Tekin, S. A. (2021). Yapay Zekâ Tabanlı Görüntü İşleme Tekniklerinin İnsansız Hava Araçları Üzerinde Uygulamaları. Avrupa Bilim Ve Teknoloji Dergisi, (24), 469-473.

Sümer, G. (2016). Türk Bankacılık Sektörünün Tarihsel Gelişimi Ve Ab Bankacılık Sektörü Ille Karşılaştırılması. Gazi Üniversitesi iktisadi Ve İdari Bilimler Fakültesi Dergisi, 18(2), 485-508.

Sürmen, Y. E. (2019). Endüstri 4.0 Ve Otomotiv Endüstrisi: Bursa İli Swot Analizi Ile Değerlendirilmesi. Bursa Uludağ Üniversitesi Sosyal Bilimler Enstitüsü Uluslararası İşletmecilik Ve Ticaret Anabilim Dalı. Yayımlanmış Yüksek Lisans Tezi. 
Şeker, E. (2020). Yapay Zekâ Tekniklerinin/Uygulamalarının Siber Savunmada Kullanımı. Uluslararası Bilgi Güvenliği Mühendisliği Dergisi, 6(2), 108-115.

Tamer, H. Y., \& Övgün, B. (2020). Yapay Zekâ Bağlamında Dijital Dönüşüm Ofisi. Ankara Üniversitesi Sbf Dergisi, 75(2), 775-803.

Topakkaya, A., \& Eyibaş, Y. (2019). Yapay Zekâ Ve Etik iliş̧kisi. Felsefe Dünyası, 70(1), 81-99.

Topsakal, Y. (2018). Akıllı Turizm Kapsamında Engelli Dostu Mobil Hizmetler: Türkiye 4.0 iç̧in Öneriler. Journal Of Tourism Intelligence And Smartness, 1(1), 1-13.

Uğur, A., \& Kınacı, A. C. (2006). Yapay Zekâ Teknikleri Ve Yapay Sinir Ağları Kullanılarak Web Sayfalarının Sınıflandırılması. Xı. Türkiye'de İnternet Konferansı (Inet-Tr'06), Ankara, 1-4.

Votintseva, L., Andreeva, M., Kovalenin, I., \& Votintsev, R. (2019, March). Digital Transformation Of Russian Banking Institutions: Assessments And Prospects. In lop Conference Series: Materials Science And Engineering (Vol. 497, No. 1, P. 012101). Iop Publishing.

Yavuz, A. E., \& Babuşcu, Ş. (2017). Türk Bankacılık Sektöründe Penetrasyon; İnternet Bankacılı̆̆ı Ve Mobil Bankacılık Ürünlerindeki Penetrasyonun Analizi. Başkent Üniversitesi Ticari Bilimler Fakültesi Dergisi, 2(1), 24-57.

Yanık, R \& Karadaş, A. (2013). E-Faturanın Türkiye Muhasebe Standartları Uyum Sürecine Uygun Düzenlenmesine Iliş̧kin Bir Öneri. EKEV Akademi Dergisi, 17(57), 133-141

Yanık, R \& Sümer, S. (2019). Akademisyenlerin İslami Bankacılık Algısı. ATASOBED, 23(3), 1177-1190

Yıldırım, B. F., \& Özdemirci, F. (2019). Kurumlarda Örtük Bilginin Yapay Zekâ Destekli Tavsiye Sistemleri Aracıllğıyla Ortaya Çıkarılması. Bilgi Yönetimi, 2(1), 34-43.

Zang, Y., Zhang, F., Di, C. A., \& Zhu, D. (2015). Advances Of Flexible Pressure Sensors Toward Artificial Intelligence And Health Care Applications. Materials Horizons, 2(2), 140-156.

Zeren, D., \& Keşlikli, i. (2019). Programatik Reklamcılık: Kavram, iş̧leyiş Ve Potansiyeli Açısından Değerlendirmesi. Çukurova Üniversitesi Sosyal Bilimler Enstitüsü Dergisi, 28(2), 312-326.

Zhang, X. Ve Dahu, W. (2019). Yapay Zekâ Algoritmalarının Görüntü İşlemede Uygulanması. Görsel İletişim Ve Görüntü Temsil Dergisi, 61, 42-49.

Zinisha, O. S., Ivanenko, I. N., \& Avdeeva, R. A. (2019). Artificial Intelligence As A Factor To Improve Bank Efficiency. Indo American Journal Of Pharmaceutical Sciences, 6(3), 6917-6919.

\section{Internet Kaynakları}

https://docs.microsoft.com/tr-tr/azure/cognitive-services/luis/what-is-lui (Erişim Tarihi 24.05.2021)

https://listelist.com/otomotiv-endustrisi-yapay-zeka/ (23.05.2021)

https://medium.com/t\%C3\%BCrkiye/yapay-zekan\%C4\%B1n-tarih\%C3\%A7esi-ve-geli\%C5\%9Fim-s\%C3\%BCrecicb4c73deb01d (Erişim tarihi 12.04.2021)

https://tr.asseco.com/coezuemlerimiz/cagri-merkezi-ve-ses-teknolojileri/coezuemler/ivn-akilli-dis-arama-sistemi-669/ (Erişim Tarihi 29.04.2021)

https://www.endustri40.com/pazarlamada-kullanilan-yapay-zeka-araclari/ (Erişim Tarihi 23.05.2021)

https://www.havelsan.com.tr/haberler/guncel/havelsan-yapay-zekali-simulator-gelistirecek (Erişim Tarihi 24.05.2021)

https://www.new.com.tr/blog/akilli-turizm-otelcilik-ve-yapay-zekâ-uygulam (Erişim Tarihi 23.05.2021)

https://www.samsung.com/tr/apps/samsung-health/ (Erişim Tarihi 20.05.2021)

https://www.ssb.gov.tr/urunkatalog/tr/154 (24.05.2021)

https://www.tbb.org.tr/tr (Erişim tarihi 03.04.2021)

https://www.turnitin.com/t (Erişim Tarihi 18.05.2021) 